1990

\title{
Law, Violence, and Illiberal Belief
}

Richard K. Sherwin

New York Law School

Follow this and additional works at: http://digitalcommons.nyls.edu/fac_articles_chapters

\section{Recommended Citation}

78 Geo. L. J. 1785 (August 1990)

This Article is brought to you for free and open access by the Faculty Scholarship at DigitalCommons@NYLS. It has been accepted for inclusion in Articles \& Chapters by an authorized administrator of DigitalCommons@NYLS. 


\title{
ARTICLES
}

\section{Law, Violence, and Illiberal Belief}

\author{
RICHARD K. SHERWIN*
}

Justice has this in common with grace, and this alone, that it wants to be total and to rule absolutely.

Politics is not religion, or if it is, then it is nothing but the Inquisition.

A. Camus $^{1}$

Our "new world": we have to realize to what degree we are the creators of our value feelings-and thus capable of projecting "meaning" into history. This faith in truth attains its ultimate conclusion in us-you know what it is: that if there is anything that is to be worshipped it is appearance that must be worshipped, that the lie, and not the truth-is divine!

Value words are banners raised where a new bliss has been found-a new feeling.

F. Nietzsche ${ }^{2}$

Feelings are a mere accompaniment to the metaphysical and metapsychical fact of the relation, which is fulfilled not in the soul but between $I$ and Thou.

\section{Buber}

These are troubled times for liberal belief. Caught between the pressures of post-modernist deconstruction on the one side and pre-modernist fundamentalism on the other, the liberal project is now being squeezed as it has never been squeezed before. ${ }^{4}$ The issue may come down to this: In a time of insecure belief, must liberal constraints upon the urge to believe come to be

* Associate Professor of Law, New York Law School.

1. A. Camus, The Rebel 114, 302 (1956).

2. F. Nietzsche, The Will To Power 523, 380 (W. Kaufman ed. 1968) (emphasis in original).

3. M. BUBER, I AND THOU 81 (2d ed. 1958).

4. See Bauman, The Communitarian Vision of Critical Legal Studies, 33 MCGILL L.J. 295, 305 (1988) (describing one strain of the critical legal studies movement as criticizing the liberal state and its legal forms for alienating members of the community, who are thereby blocked from realizing their common interests); see also S. HAUERWAS, A COMMUNITY OF CHARACTER 84 (1981) ("[F]or Christians our authority is neither in society itself nor in the individual; it is in God. As a result the church must stand as a reminder to the pretensions of liberalism that in spite of its claims to legitimate authority, some necessarily rule over others as if they had the right to command obedience." (footnote omitted)); M. PerRY, Morality, Politics, and Law 57 (1988) ("The liberal politicalphilosophical project is spent. It is past time to take a different path."); Fish, Liberalism Doesn't Exist, 1987 Duke L.J. 997, 1000-01 (asserting that liberalism does not exist because its claim to objective or neutral principles cannot be maintained); Littleton, Feminist Jurisprudence: The Dif- 
regarded as an unnecessary encumbrance? Has belief in liberal ideals grown so thin that the "true believer" feels compelled to rebel-perhaps to emancipate belief itself ?

ference Method Makes (Book Review), 41 STAN. L. REv. 751, 761 (1989) ("Liberalism cannot offer more than an empty picture of the person, a vacuum to be filled by those in power.").

Perry's prophecy, and Hauerwas' and Fish's critiques, lose much of their substance, however, when we realize that the ideal of neutrality that they attribute to liberalism is by no means a necessary part of the liberal vision. See infra note 30 and text accompanying note 31 (modifying Ackerman's "neutral discourse" principle by stripping it of passivity and positing it as a normative ideal). One may also question Perry's apparent assumption that participants in incommensurable moral discourses can simply "talk out" their differences. See M. PERRY, supra, at 51, 53. This view, while laudable, seems to overlook the history of religious intolerance and the realities of dialogic closure that gave birth to, and continue to justify, the liberal standpoint. See F. BACON, Of Unity in Religion, in THE EsSAYS of Francis BACON 10, 10 C. Northup 10th ed. 1936) ("But the true God hath this attribute, that he is a jealous God; and therefore his worship and religion will endure no mixture nor partner." (emphasis in original; footnote omitted) (citing Exodus 20:3-6)).

5. See Cover, The Supreme Court, 1982 Term-Forward: Nomos and Narrative, 97 HARv. L. REv. 4, 68 (1983) [hereinafter Cover, Nomos] ("We ought to stop circumscribing the nomos; we ought to invite new worlds."). Some observers of Western culture have suggested that the trouble may lie with belief itself. See E. Durkheim, Suicide 386, 364 (1951) ("If more suicides occur today than formerly, [it is] because we no longer know the limits of legitimate needs nor perceive the direction of our efforts." "The entire morality of progress and perfection is thus inseparable from a certain amount of anomy."); Eisenstadt, Introduction to M. WEBER, ON CHARISMA AND INSTITUTION BuILDING at liv-lv (describing Weber's sense that modern society's success in allowing participation, along with the bureaucratization of this participation, has demystified the world, correlatively creating apathy toward goals and values that have been shom of mystery's charisma); $c f$. P. BERGER, THE SACRED CANOPY 152 (1967) ("The religious traditions have lost their character as overarching symbols for the society at large, which must find its integrating symbolism elsewhere.").

One may ultimately reject generalizations regarding the decline in belief, but at first glance such claims may not appear surprising. When a particular belief cannot be shored up-or restoredwithin some new context of meaning, it may well seem as if belief itself has been frustrated. For example, Richard Bernstein describes the "Cartesian anxiety" experienced by those whose belief in foundationalist (i.e., eternal and immutable) values can only register in the form of profound disappointment, a kind of negative echo, when faced with the antifoundationalist (or hermeneutic) insights of contemporary philosophy. R. BERNSTEIN, BEYOND OBJECTIVISM AND RELATIVISM 1625 (1983). A rather similar despondency has emerged within the current legal culture as it confronts the antifoundational "interpretive turn" that Bernstein describes. See Fiss, Objectivity and Interpretation, 34 STAN. L. REv. 739, 740-41 (1982):

This new nihilism might acknowledge the characterization of adjudication as interpretation, but then would insist that the characterization is a sham. The nihilist would argue that for any text-particularly such a comprehensive text as the Constitution-there are any number of possible meanings, that interpretation consists of choosing one of those meanings, and that in this selection process the judge will inevitably express his own values. All law is masked power.

Cf. S. Levinson, Constitutional FartH 52 (1988) (noting that "[t]he 'death of constitutionalism' may be the central event of our time"). The uncertainty that characterizes the contemporary scene stems, according to Levinson, from the fact that "[m]any in our culture" (apparently including Levinson himself) are unable either to believe in "the persuasive force of detached reason" or "to make a "leap of faith." "Id. This stark depiction of reality, as if there were no alternative but to 
In this article, I offer a post-modernized liberal response ${ }^{6}$ to the claims of both underbelievers (i.e., radical relativizers who say the ongoing flux of coequal "truths" is all there is) 7 and overbelievers (i.e., sectarians who assert that the chaos of normative relativity must be surmounted by the reign of "Truth"). ${ }^{8}$ I contend that rebellion against liberal constraints, now as in the past, not only raises the specter of violent discord, but also risks tyranny. ${ }^{9}$

choose between neutral rationality and some supra-rational authority, bears a distinctly Cartesian flavor.

Only when a particular belief has been fully disengaged from general acceptance does it come to be recognized as a mere idol or myth, rather than as a continuing source of nostalgia, despair, or anxiety. Only then, moreover, can alternative beliefs emerge as real possibilities. Before that point, even a waning belief will stand for the act of belief writ large. Held in the grip of a particular belief, we forget that the need to believe remains constant, only its substance changes. $C f$. E. CASSIRER, LANGUAGE AND MYTH 11 (1946) ("[I]t is not a question of what we see in a certain perspective, but of the perspective itself."). The rise of rhetoric (in association with the resurgence of hermeneutic philosophy) will come into its own when the spell of Cartesian anxiety finally passes. See Sherwin, A Matter of Voice and Plot: Belief and Suspicion in Legal Storytelling, 87 MICH. L. REV. 543, 562, 565-66 (1988).

6. See infra Part IV (using existential and hermeneutic perspectives on committed ethical imagination, conditioned by the principle of discursive constraint, to take the place of classical "neutralistic" and sectarian strains within liberal theory). For an example of the latter, see J. LockE, A LETTER CONCERNING TOLERATION 171-76 (C. Sherman ed. 1965) (opposing coercive proselytizing by civil authorities on the ground that it is unacceptable to God), and id. at 212-13 (requiring the exclusion of atheists from civil society because they feel nothing to bind their promises, their denial of God "dissolves all" and "destroy[s] all religion," and they lack the very beliefs that make toleration desirable). With regard to liberalism's putative claim to neutrality, consider B. ACKERMAN, Social Justice IN THE Liberal STATE 10-15 (1980) and my critique infra note 30.

The term "post-modern" is notoriously difficult to define. I use it here to refer primarily to those movements in twentieth century continental thought known as "existentialism," "phenomenology," and "hermeneutics." As John Caputo has pointed out, the common denominator that links these movements is "a concerted effort to put man back in touch with himself." Caputo, The Thought of Being and the Conversation of Mankind: The Case of Heidegger and Rorty, in HERMENEUTICS AND PRAXIS 248, 264 (R. Hollinger ed. 1985). This also describes the main idea behind the effort to "overcome metaphysics" (i.e., living with the realization that there is no ahistorical, universal, or foundational truth awaiting discovery and thus there is no escape from the uncertainties that attend finite human judgment and understanding). As Caputo puts it, the attack upon metaphysics "has been aimed at reawakening a sense of the human drama, at recovering the lived quality of our experience and the historicality of the dialogue into which we have all been entered." Id. at 265 . This understanding comports well with what I have described as the rise of rhetoric. See Sherwin, supra note 5 , at 563-68.

7. According to Peter Berger, this approach is a way of making the socio-cultural world "appear once more as a contingent, historical construction of [humans]." P. BERGER, supra note 5, at 97-98; see id. at 96-98 (referring to the "legitimat[ion]" of "de-alienation," especially in the context of religious perspectives such as Hinduism, on the basis of which traditional religious legitimations, previously taken for granted, are relativized and perhaps invalidated); see also R. RORTY, PHILOsoPHY AND THE MIRROR OF NATURE 357-79 (1979), and his jurisprudential disciple, Sanford Levinson, supra note 5, at 51-53.

8. See, e.g., S. HAUERWAS, supra note 4, at 48 ("[T] he 'truth' turns out to be that if we are to follow him we must learn to lose our lives, not as an end in itself, but for 'his sake.' . . There is no truth beyond him: His story is the truth of the Kingdom. And that truth turns out to be the cross.").

9. See Everson v. Board of Educ., 330 U.S. 1, 8-16 (1947) (finding purpose of the establishment 
Thus, whether the rebellion comes out of sheer anarchic joy in the face of multiple possible worlds ${ }^{10}$ or traditional Judeo-Christian sources, ${ }^{11}$ as a phenomenon within the legal culture it warrants close critical scrutiny.

No amount of criticism, however, will take the place of ideals that inspire belief. The hope that drives this article is that by revitalizing liberal idealsa task that involves both historical recollection and creative re-imaginationthe temptation to rely upon sectarian overbelief to counter political underbelief will be resisted.12 In order to retrieve the persuasive force of the liberal vision, it will be necessary at the outset to reconstitute, both theoretically and practicably (which is to say, in a way that promotes collective consensus on) the foundational ideals that the liberal vision embodies. ${ }^{13}$ I submit that untrammeled discourse describes one such ideal. ${ }^{14}$

clause to be avoidance of the "turmoil, civil strife, and persecutions" occasioned by the coincidence of church and state).

10. For expression of this anarchic joy, see F. NIETzSche, supra note 2; see also E. GRASSI, Renaissance Humanism: Studies in Philosophy and Politics 90 (1988) (" 'Moria' does not stand simply for a way of being human, for a human condition, namely, folly. It is also the epitome of the appealing power through which all being manifests itself in its semantic significance; it is the pervasive power, which cannot be explained or derived: the unfathomable."); Cornell, Taking Hegel Seriously: Reflections on Beyond Objectivism and Relativism (Book Review), 7 CARDozo L. REV. 139, 181, 183 (1985) ("[Duncan] Kennedy shares with Feyerabend and Kuhn a vision which insists on rupture, break and negativity. . . . The irrationalist view of indeterminacy as complete unconstraint can itself be seen as an expression of the corrosion of sittlich [or socially situated] commitments with their pull to a shared social reality. This understanding of indeterminacy is radical individualism taken to its dialectical conclusion."); Cover, Nomos, supra note 5, at 68 ("We ought to stop circumscribing the nomos; we ought to invite new worlds.").

For one of the most profound visions of multiplicity ever recorded, consider the experience of the warrior Arjuna in ThE Bhagavad GrTa 90 (J. Mascaro trans. 1962) ("And Arjuna saw in that form countless visions of wonder: eyes from innumerable faces, numerous celestial ornaments, numberless heavenly weapons; celestial garlands and vestures, forms anointed with heavenly perfumes. The Infinite Deity was facing all sides, all marvels him containing.").

11. See, e.g., S. HaUERwaS, supra note 4, at 83-86; M. PERRY, supra note 4, at 136-45.

12. My hope is that this article's depiction of illiberal belief will serve both substantively to contextualize a post-modernized liberal ideal and to underscore the urgency of this recreative task. A more encompassing effort-in which others, including Rawls, Ackerman, Dworkin, and Rorty are also currently engaged-is necessary before this task can be accomplished.

13. See A. Rapaczynski, Nature and Politics: Liberalism IN THE Philosophies of HobBes, LOCKE, AND RouSSEAU 288-91 (1987) (describing the need for liberal theorists to come up with a more comprehensive theory of persons and community so that the traditional oscillation between utilitarianism and Kantianism, which so far has failed to meet the Rousseauian critique of social atomism, may be transcended); Sherwin, Opening Hart's Concept of Law, 20 VAL. U.L. REV. $385,407-10$ (1986) (describing the need to obtain collective agreement on foundational norms in order to legitimate them); cf. Rawls, Justice as Fairness: Political not Metaphysical, 14 PHIL. \& PUB. AFF. 223, 225-26 (1985) (describing the political conception of "justice as fairness" as depending upon an "overlapping consensus" that includes diverse and opposing philosophical and religious doctrines).

14. I shall contend that the discourse ideal not only captures the individual autonomy (dignity/ integrity) aspect of liberalism, but also addresses the so-called communitarian "lack" that critics of liberalism have traditionally seized upon. For a concise account of Rousseau's and Marx's criticisms of liberalism's communitarian "lack," and a cry for a systematic retort, see A. RAPACZYNSKI, 
As an ideal, discourse embodies both structural checks and emancipatory empowerment. The freedom that untrammeled discourse allows cannot exist without appropriate legal restraints. ${ }^{15}$ Instituting discursive ${ }^{16}$ limits upon governmental and nongovernmental agencies of power curbs the natural in-

supra note 13, at 287-91 (discussing how self-interested actions of individuals destroy or deny communitarian values and efforts).

For insight into a "dialogic" ideal's communitarian strength, see Cornell, Institutionalization of Meaning, Recollective Imagination and the Potential for Transformative Legal Intepretation, $136 \mathrm{U}$. PA. L. REv. 1135, 1143, 1194, 1211-24 (1988) [hereinafter Cornell, Institutionalization] (using Hegel's notion of social reality (Sittlichkeit) as a basis for dialogic or narrative-based communitarian order); see also B. AcKERMAN, supra note 6, at 70-80 (describing the necessary conditions for citizenship in terms of "dialogic performance"); Cornell, supra note 10, at 169-74 (describing Bernstein's "pragmatic Hegelian recasting of dialogism" as another effort to reconcile communitarianism with individualism); Handler, Dependent People, the State, and the Modern/ Postmodern Search for the Dialogic Community, 35 UCLA L. REv. 999, 1074-86 (1988) (describing "trust" as one factor necessary to form a participatory dialogic community); Michelman, Law's Republic, 97 Y ALE L.J. 1493, 1503-07, 1524-32 (1988) (recognizing validity and necessity to modern republicanism of dialogue throughout all of society); $c f$. Rubin, The Practice and Discourse of Legal Scholarship, 86 MICH. L. REv. 1835, 1893 (1988) (describing the "most promising" discourse for legal scholarship as one that uses "prescriptive arguments based on consciously acknowledged normative positions"); Sherwin, Dialects and Dominance: $A$ Study of Rhetorical Fields in the Law of Confessions, 136 U. PA. L. REv. 729, 734-49, 824-47 (1988) (describing discrete dialects of law and the idea of a dialogic institution of intrajudicial checks and balances).

From Isocrates to Heidegger, it has been well settled that language is what makes humans human. See Isocrates, Antidosis, in 2 Isocrates 179, 327 (G. Norlin trans. 1968) ("[B]ecause there has been implanted in us the power to persuade each other and to make clear to each other whatever we desire, not only have we escaped the life of wild beasts, but we have come together and founded cities and made laws and invented arts ...."); M. HEIDEGGER, ON THE WAY TO LANGUAGE 112 (P. Hertz trans. 1971) ("The ability to speak is what marks man as man ... . We are, then, within language and with language before all else."). Accordingly, the discourse ideal of dialogic liberalism seeks to recollect, and to safeguard above all else, the value of that which is most fundamental to our humanity: namely, discourse itself.

15. See E. Levinas, Freedom and Command, in Collected Philosophical Papers 15, 17 (1987):

To conceive of and to bring about a human order is to set up a just State, which then is the possibility of surmounting the obstacles that threaten freedom. It is the only way to preserve freedom from tyranny .... Here then is our conclusion at this point: we must impose commands on ourselves in order to be free. But it must be an exterior command, not simply a rational law, not a categorical imperative, which is defenseless against tyranny; it must be an exterior law, a written law, armed with force against tyranny. Such are commands as the political condition for freedom.

See also Walker v. City of Birmingham, 388 U.S. 307, 320-21 (1966) (involving civil rights demonstrators' violation of a preliminary injunction against public march):

The rule of law that Alabama followed in this case reflects a belief that in the fair administration of justice no man can be judge in his own case, however exalted his station, however righteous his motives, and irrespective of his race, color, politics, or religion .... One may sympathize with the petitioners' impatient commitment to their cause. But respect for judicial process is a small price to pay for the civilizing hand of law, which alone can give abiding meaning to constitutional freedom.

Cf. Plato, The Crito, in The Collected Dialogues of Plato 27, 35 (E. Hamilton \& H. Cairns ed. 1961) ("Shall we say, Yes, I do intend to destroy the laws, because the state wronged me by 
clination to privilege one's own set of beliefs and discourse above others. ${ }^{17}$ Left unconstrained, an official language of power tends to totalize its control-leaving those who would speak in a different voice to a disempowered silence. ${ }^{18}$ By diffusing power among discrete discursive communities, institutional constraints help to preserve the full potential of diverse communicative practices. Indeed, discursive enrichment is not only the purpose of such constraints, but also a measure of their legitimacy. ${ }^{19}$

passing a faulty judgment at my trial?" Refusing exile and accepting death at the hands of the state, Socrates, in Plato's account, answers, "No.").

To be sure, this is not to say that governmental power is unconstrained; the constraints that government may impose upon others is limited in principle. See, e.g., Trop v. Dulles, 356 U.S. 86, 102-03 (1958) (plurality) (condemning an act of Congress that imposed the punishment of banishment (i.e., loss of citizenship) for the crime of desertion, arguing that the ensuing imposition of statelessness is a "cruel and unusual" punishment forbidden by the eighth amendment: "[T]he expatriate has lost the right to have rights. This punishment is offensive to cardinal principles for which the Constitution stands.").

16. Unlike the term "dialogic," which conveys the image of two persons conversing, the term "discursive" is used to convey multiple conversations involving diverse forms of speech, knowledge, and persuasion.

17. See Rawls, supra note 13, at 249:

Until the Wars of Religion in the sixteenth and seventeenth centuries, the fair terms of social cooperation were narrowly drawn: social cooperation on the basis of mutual respect was regarded as impossible with persons of a different faith. ... Thus one of the historical roots of liberalism was the development of various doctrines urging religious toleration.

See also Prince v. Massachusetts, 321 U.S. 158, 175-76 (1944) (Murphy, J., dissenting) ("From ancient times to the present day, the ingenuity of man has known no limits in its ability to forge weapons of oppression for use against those who dare to express or practice unorthodox religious beliefs."); Cantwell v. Alabama, 310 U.S. 296, 310 (1940) ("The danger in these times from the coercive activities of those who in the delusion of racial or religious conceit would incite violence and breaches of the peace in order to deprive others of their equal right to the exercise of their liberties, is emphasized by events familiar to all [referring to Nazi Germany]. These and other transgressions of those limits the States appropriately may punish.”); B. ACKERMAN, supra note 6, at 8-10 (advocating constrained power talk as the organizing principle of liberal thought).

18. See Sherwin, supra note 14, at 848 ("As a particular dialect [of legal discourse] gains ascendancy, alternative ways of thinking and speaking either become nonsensical ("incoherent") or irrelevant to the ruling discourse, or are captured and reformed by the dominant dialect through a process of systematic "translation." Familiar words lose their old meanings. The appearance of continuity belies a thorough reconstruction of narrative reality; the possibilities of meaning are closed down.")

19. See Whitney v. California, 274 U.S. 357, 375-76 (1926) (Brandeis, J., with Holmes, J., concurring) (footnote omitted):

Those who won our independence believed that the final end of the State was to make men free to develop their faculties; and that in its government the deliberative forces should prevail over the arbitrary.... They believed that freedom to think as you will and to speak as you think are means indispensable to the discovery and spread of political truth ... that public discussion is a political duty; and that this should be a fundamental principle of the American government. . . Believing in the power of reason as applied through public discussion, they eschewed silence coerced by law-the argument of force in its worst form.

Cf. J. Dewey, Reconstruction in Philosophy 211-13 (1957) (on unleashing individual poten- 
In pursuit of the discourse ideal, liberalism affirms the right of each of us to voice interests or claims of entitlement in the face of the other's, or the state's, power. ${ }^{20}$ This is a right not only to speak, but also to be heard. For true dialogue can only proceed respectfully, with each party intent on both understanding and being understood by the other. ${ }^{21}$ Accordingly, persuasion (when it does not deceive) is the hallmark of the dialogic process. ${ }^{22}$ In contrast, discourse that claims the authority of "prophetic revelation," or that posits the incontestable authority of some extralegal "sacred text," cannot provide adequate reasons to persuade the unconverted other. Indeed, it leaves room for but two responses: conversion (which is to say, either accepting the other's belief on faith, or enforcing one's own) or exile (which is to say, silence). By excluding individuals or discrete communities and their respective discourses from the dialogic process, illiberal discourse mocks the liberal ideal. From this account, the following principle of non-sectarian discursive constraint emerges: When a claim that seeks the state's backing can rely only upon assertions that alienate those who stand outside the claimant's subjectively preferred sectarian belief system, the claim in question should be rejected as an illegitimate object of state power. This fundamental liberal principle of non-sectarian discursive constraint effectively safeguards majorities and minorities alike against the tyranny of state empowered illiberal

tial). That the norms and institutional practices of discursive constraint must be widely understood and accepted is the sine qua non of power's legitimation in the liberal state. Cf. Ackerman, Beyond Carolene Products, 98 HARv. L. REv. 713, 742 (1985) (referring to the "fundamental commitments" that bind together "We the People" and limit pluralist bargaining); Cornell, supra note 10, at 183 ("We are constrained by otherness as we find ourselves in and through it." (emphasis in original)).

20. See B. Ackerman, Reconstructing American LAw 97-101 (1984) (the ideal of liberal dialogue demands a structure of "undominated equality"); $c f$. Procunier v. Martinez, 416 U.S. 396, 419 (1974) (describing the indigent prisoner's right to meaningful access to the courts as a consequence of the constitutional guarantee of due process of law); Gideon v. Wainwright, 372 U.S. 335, 344 (1963) (mandating state appointment of counsel for indigent defendants in all criminal prosecutions); Powell v. Alabama, 287 U.S. 45, 69 (1932) (noting that even the intelligent and educated nonlawyer requires the guiding hand of counsel at every step in the proceeding against him and that "[i]f in any case, civil or criminal, a state or federal court were arbitrarily to refuse to hear a party by counsel ... it reasonably may not be doubted that such a refusal would be a denial of a hearing, and, therefore, of due process in the constitutional sense."). But $c f$. Pennsylvania v. Finley, 481 U.S. 551, 555-57 (1987) (noting that an indigent prisoner has no equal protection or due process right to appointed counsel in pursuing a discretionary appeal or on direct review of a conviction that has become final upon exhaustion of the appellate process); Murray v. Giarratano, $109 \mathrm{~S}$. Ct. 2765, 2768-69 (1989) (extending Finley to capital cases).

21. See Minow, The Supreme Court, 1986 Term-Foreword: Justice Engendered, 101 HARv. L. REV. 10, 14-16, 70-95 (1987) (a commitment to seeking out and listening to perspectives other than one's own is integral to approaching the "dilemma of difference").

22. Thus the rise of rhetoric. See J. White, Heracles' Bow: EsSAys on the RHEToric AND POETICS OF THE LAW passim (1985) (law as rhetorical and literary activity); Sherwin, supra note 14 , at 735-49 (phenomenology of rhetorical dialects in the context of criminal procedure). 


\section{belief. $^{23}$}

When dialogic persuasion flourishes in society, we witness the revitalization not only of the political and legal dimensions of liberalism, but also of its dynamic cultural dimension. With a renaissance of liberal belief we may discover anew the collective and ongoing rhetorical (re)constructions of self, other, and community that untrammeled discourse both invites and inspires. ${ }^{24}$ Simply put, belief in the discourse ideal restores communication as a way of life. ${ }^{25}$

In order to proceed toward this reimagined liberal ideal, however, the rebellion against restraint-regardless of what side of the political spectrum the rebellion comes from-must be directly confronted. In a time of uncertain belief, the danger of romantic excess is strong. Illiberal belief loves noth-

23. See Audi, The Separation of Church and State and the Obligations of Citizenship, 18 Punt. \& PUB. AFF. 259, 294 (1989) ("[W] here extensive, conscientious use of secular reasoning cannot decide whether a kind of conduct is morally permissible, that conduct should not be prohibited by law."); see also P. LEVI, THE REAWAKENING 214-15 (1965) ("It is, therefore, necessary to be suspicious of those who seek to convince us with means other than reason, and of charismatic leaders ... Since it is difficult to distinguish true prophets from false, it is well to regard all prophets with suspicion.").

And if it is a liberal claimant who "alienates" the illiberal other? The response cannot be evaded: even the liberal state must reserve the right, accorded to it by the consent of the governed, to back up its shared fundamental norms with force if need be. See infra note 32.

24. Cf. G. Pico, ON THE DignitY OF MAN 23 (1965) ("by [the] comparison of very many sects and by the discussion of manifold philosophy, that radiance of truth ... might shine more clearly upon our minds"); Caputo, supra note 6, at 264-65 (aim of liberal belief is to "make of philosophy a concerted effort to put man back in touch with himself ... [ [to recover] the lived quality of our experience and the historicality of the dialogue into which we have all been entered"); P. KRISTELLER, Paduan Averroism and Alexandrism in the Light of Recent Studies, in RENAISSANCE ThOUghT AND THE ARTS: Collected ESSAYS 111, 115 (1980) (linking secular Aristotelianism and the idea of equally true opinions with the Renaissance ideal of philosophical and scientific liberty); White, What Can $A$ Lawyer Learn from Literature? (Book Review), 102 HARV. L. REV. 2014, 2015 n.3 (1989) (describing the law and literature (or "law and humanities") movement as a "return to a sense of law as a humanistic discipline that has its modern roots at least as early as the Renaissance.").

25. See L. Fuller, The Morality of LAW 186 (1969) ("Communication is something more than a means of staying alive. It is a way of being alive. It is through communication that we inherit the achievements of past human effort. .. . How and when we accomplish communication with one another can expand or contract the boundaries of life itself. In the words of Wittgenstein, 'The limits of my language are the limits of my world." ").

Although I cannot address the matter in detail given the scope of the present article, it warrants emphasizing that the liberal discourse ideal cannot legitimate state authority without broad acceptance of the obligations of substantive equality. See infra text accompanying notes 179-188. Ronald Dworkin has specifically addressed this issue in a four-part series of articles in which he explores from different perspectives the abstract egalitarian principle that "government must act to make the lives of citizens better, and must act with equal concern for the life of each member." Dworkin, What is Equality? Part 4: Political Equality, 22 U.S.F. L. REv. 1 (1987). For a different approach to the same issue, see Rosenfeld, Decoding Richmond: Affirmative Action and the Elusive Meaning of Constitutional Equality, 87 Mich. L. REv. 1729, 1734 (1989) (arguing that it is impossible to come to any principled conclusion regarding the constitutionality of affirmative action without subscribing to a particular conception of substantive equality). 
ing so much as uncertainty, for uncertainty provides the opening that illiberal belief needs to assert its force. As illiberal belief rushes toward power, the disempowerment of the disbelieving other cannot be far behind. ${ }^{26}$

While the goal of my critique is to underscore the danger in our time of illiberal belief, the critique also bares (bears) an affirmative twist. Ironically, my conclusion is that it is precisely in the face of illiberal beliefs that liberalism finds its clearest and most vigorous measure. Repulsing the chaos of conflicting normative realities on the one side, and the tyranny of a single, totalizing belief system on the other, liberalism attains its proper rhythm. It emerges as a dialogic pulse bound between belief and power. ${ }^{27}$

26. Cf. P. BERGER, supra note 5 , at $48-49$ :

When an entire society serves as the plausibility structure for a religiously legitimated world, all the important social processes within it serve to confirm and reconfirm the reality of this world. ... The "social engineering" problem in such a situation ... involves ... the upkeep of effective controls over dangerous or potentially dangerous deviants ....

This view has been echoed by others. See Lynch v. Donnelly, 465 U.S. 668, 688 (1984) (O'Connor, J., concurring) (governmental endorsement of religion is invalid to the extent that it "sends a message to nonadherents that they are outsiders, not full members of the political community, and an accompanying message to adherents that they are insiders, favored members of the political community."); F. BACON, supra note 4, at 12 (noting the New Testament credo: "[h]e that is not with us is against us")(emphasis in original)); THE BHAGAVAD GITA, supra note 10, at 52 ("There is no greater good for a warrior than to fight in righteous war.").

It may perhaps be unnecessary to note, in a century as brutal as ours, that throughout history ideological as well as religious fervor has contributed to immoderate violence. Consider, for example, Stalin's secret gulags, Kampuchea's genocidal self-transformation in the name of utopian socialism, France's post-revolutionary Reign of Terror, or the lesser known violent repression that took place at Vendee, France, following the fall of the Bastille in 1789, and in the course of which it is estimated that between 300,000 to 600,000 people lost their lives. See Markham, In a Corner of France, Long Live the Old Regime, N.Y. Times, June 17, 1989, at 2, col. 1.

27. By redirecting our attention to this dialogic origin, a post-modernized account of liberalism recalls afresh that the key to the legitimacy of self-government under law lies in the way we deal with violence-whether it is the violence of the state or the violence of private individuals. $C f$. J. LOCKE, supra note 6, at 171 ("I esteem it above all things necessary to distinguish exactly the business of civil government from that of religion, and to settle the just bounds that lie between the one and the other.").

The dialogic pulse can be felt as it beats against the dispiriting forces of political dictation and public (often officially induced) babel. The recent rebellion against tyranny in Eastern Europe refiects the resiliency of this dialogic impulse. It also points up the close relation that exists between discourse and power. See, e.g., M. FouCAUlt, The Discourse on Language, in The ARCHAEOLOGY OF KNOWLEDGE 229 (1972) ("We must conceive discourse as a violence that we do to things, or, at all events, as a practice we impose upon them ..."); Havel, Words on Words, N.Y. REv. Books, Jan. 18,1990 , at 5,5 ("[W] have always believed in the power of words to change history ...."). Havel also notes that responsibility for and toward words is a task that is intrinsically ethical: "Words that electrify society with their freedom and truthfulness are matched by words that mesmerize, deceive, inflame, madden, beguile, words that are harmful-lethal, even. The word as arrow." Id.

An even more graphic manifestation of the link between discourse and power may be seen in the pitched battles for the control of national broadcasting facilities that quickly became the physical and symbolic focal point of the violent Romanian uprising in the last days of December 1989. 
From the modernist tradition, we have learned to remain vigilant against the threat of absolute power that attends the politicization of absolute beliefs. ${ }^{28}$ With the aid of significant post-modernist insights (such as the existential insight regarding the human need for meaning, especially in the form of constitutive narrative), ${ }^{29}$ we also have learned to be vigilant against the modernist tendency to neutralize political belief ${ }^{30}$-as if neutrality could hold a culture, or a nation, together. What a post-modernized account of liberalism has to offer, therefore, is a way of thinking through the modernist era $^{31}$ without falling prey either to the anomie of neutralized belief on the one hand or the fervor of totalized belief on the other. The normative ideal of untrammeled discourse offers a middle way. For in this dialogic ideal we find not only a crucial legitimating condition for political belief (namely, re-

28. See A. Rosenberg, The Myth of the Twentieth Century: An Evaluation of the Spiritual-INTEllectual Confrontations of OUR AGE 326 (1982) ("A belief, a mythos, is only real when it has grasped the entire man."). This urge toward totalized belief also ran through another of National Socialism's inspired believers. See A. HrTLER, MEIN KAMPF 680 (1940) (referring to Nazism as above all "construction and conformation of its vision of the world."); cf. Rawls, The Domain of the Political and Overlapping Consensus, 64 N.Y.U. L. REv. 233, 249 (1989) ("[A] free democratic society well-ordered by any comprehensive doctrine, religious or secular, is surely utopian in a pejorative sense. Achieving it would, in any case, require the oppressive use of state power.").

29. See Sherwin, supra note 5, at 551 (revealing the existential predicament manifest in desiring belief, yet fearing deception); infra notes 139-154 and accompanying text.

30. See B. ACKERMAN, supra note 6, at 11 ("[n]o reason is a good reason if it requires the power holder to assert... that his conception of the good is better than that asserted by any of his fellow citizens"); $c f$. Turner, Social Dramas and Stories About Them, in ON NARRATIVE 137, 162 (W. Mitchell ed. 1980) ("Modernity means the exaltation of the indicative mood" as opposed to "antistructural" or "transformative" subjunctivity).

Applying Cover's understanding of interpretive commitment, see infra note 32, in the context of liberal belief, we can say that acceptance of liberal principles legitimates the use of state power to protect dialogic constraints from illiberal encroachment. As we shall see, in contrast to Cover's more encompassing "polynomial" approach, the liberal perspective reflects a decisive commitment to a particular normative framework. This commitment excludes (by force, if need be) other normative possibilities, including Cover's subsequent post-messianic vision.

Thus, modifying Ackerman on this point, instead of relying upon a "neutral" principle of discourse, one may say that liberalism's dialogic constraints rely upon a preferred normative belief. Indeed, it is by virtue of this foundational belief that competing normative claims (i.e., illiberal beliefs) are deprived of legitimacy. It may be that within the normative field generated by liberalism's constraint upon power, the liberal norm of constraint may seem to act as a "neutral" principle. But this appearance of neutrality is simply the effect of the normative system within which it operates. It is like looking at red letters through a red filter: the letters disappear. On this analysis, then, the liberal principle of constraint is itself a privileged norm that, contrary to Ackerman's neutrality principle, does claim to be better than, and intrinsically superior to, alternative legitimizing norms that may be asserted by advocates of illiberal political designs.

31. Let it be emphasized here that "thinking through" does not mean repudiating. Rather, the phrase suggests the dual notion of "living with" and "moving beyond." (The Hegelian term aufhebung nicely captures this dual sense of "conservation" and "raising up.") That the National Socialist movement of the 1930 s also reflects a rethinking of modernist rationality and the liberal tradition is a pointed reminder of the dangers associated with efforts to repudiate history in order to regain the potency of belief. 
spect for the dignity and worth of the other), but also an authorized measure for belief's constraint (namely, the extent to which acting in the name of a belief leads to unacceptable force being used against-thereby dominating and silencing-the other).

In this article, I argue that the liberal ideal of untrammeled discourse warrants our interpretive commitment. ${ }^{32} \mathrm{My}$ critique of illiberal belief will focus specifically upon the later writings of Robert Cover. However, to the extent that Cover's romanticism is exemplary of those who are willing to create law out of some new bliss, if not out of a more traditional (albeit no less totalizing) extralegal belief system, ${ }^{33}$ I hope that the critique will also prove exemplary. By calling into question one particular strain of illiberal belief, I hope to caution against the temptations of romantic excess in contemporary legal theory and practice generally. The best measure of success in this venture is the extent to which the lessons of illiberal belief add to the persuasive lustre of liberal ideals.

Part I traces the anarchic impulse within Cover's pre-messianic writings. Here we encounter Cover's vision of multiple communities being spawned by an endless flow of newly created meanings. Part II describes Cover's messianic turn. Here we see how Cover's earlier invitation to let multiple worlds unfold without state interference may be seriously threatened once we take up position within a particular privileged belief system - especially when that belief system obtains messianic stature. Part III criticizes Cover's pre-messianic bifurcation of the law's meaning and the law's power structure. Here we examine how Cover's separation of meaning and structure helps make possible the dangerous leap from tolerance of multiple worlds to closure within a world "redeemed" by totalized meaning.

Part IV presents a post-modernized (or existential/hermeneutic) alternative to Cover's idealized account of meanings as "crystals completely pure." The post-modernized liberal ideal described in this Part seeks to chart a course between legal meaning's endless multiplicity and its totalitarian potential. Here we see in preliminary fashion how the discursive practices of discrete communities of power reflect and maintain the discourse ideal. On this analysis, only broad participatory discourse, united by shared normative ideals, can legitimate a common public world. Yet, it is precisely in the

32. See Cover, Nomos, supra note 5 , at 7 ("The normative universe is held together by the force of interpretive commitments-some small and private, others immense and public. These commitments-of officials and of others-do determine what law means and what law shall be."); see also id. at 45 ("The transformation of interpretation into legal meaning begins when someone accepts the demands of interpretation and, through the personal act of commitment, affirms the position taken.").

33. In some cases, driven perhaps by a misplaced protest against scientistic modernism, the appeal valorizes values as a form of passion. See supra text accompanying note 2 . 
search for a common basis for union-and by extension, for the legitimation of state power-where Cover's analysis falls short.

The final part of this article seeks to give Cover's post-messianic viewpoint a more concrete embodiment by situating it in a specific historical setting. Here, in the context of the battle against slavery, we reencounter the principle of nonsectarian constraint. We shall find that this basic liberal principle contrasts sharply with the views of those who would, through sectarian violence, repudiate our historically shared public world. The article concludes that civilizing violence through principled, non-sectarian discursive constraint describes an originary legitimating measure by which our liberal constitutional heritage will stand or fall.

\section{UnStated Multiple Worlds: The ANARChic Vision}

In a series of brilliantly written articles, ${ }^{34}$ Robert Cover both supported and checked the discursive or interpretive turn within the current legal culture. He argued that our renewed appreciation of the narrative aspect of law, while valuable in a limited sense, might well prove naive in practice. Law may involve textual interpretation, Cover conceded, but unlike poetry and literature, legal interpretation takes place in a field of pain and death. ${ }^{35}$ The violence of the law, according to Cover, must be placed at the center of our understanding of what law is. ${ }^{36}$

I believe we are indebted to Cover for cautioning us against an uncritical acceptance of law as narrative. The reality of the law's coercive force, even if Cover may have overstated its scope, must not be overlooked. Indeed, I submit that Cover himself should be read with the reality of legal violence in mind. This is particularly important in light of the significant shift that his thinking underwent toward the end of his life.

In his mature work, Cover insisted that law served as both a bar and a bridge between our visions and reality. He believed that the law "rescue[d] us from . . . eschatology"; ${ }^{37}$ it held the present apart from redemption, leaving the latter within "the shadow of the millennium." 38 In his final essay, however, this separation between vision and reality came to be viewed as an "obvious fallac[y]." 39 The law was now understood as that which "connects the

34. Cover, The Bonds of Constitutional Interpretation: Of the Word, the Deed, and the Role, 20 GA. L. REv. 815 (1986) [hereinafter Cover, Bonds]; Cover, Nomos, supra note 5; Cover, Violence and the Word, 95 YALE L.J. 1601 (1986) [hereinafter Cover, Violence].

35. See Cover, Nomos, supra note 5, at 6; Cover, Violence, supra note 34, at 1606-07.

36. Cover, Violence, supra note 34, at 1628.

37. Cover, Nomos, supra note 5, at 10.

38. Id. at 9 .

39. Cover, Bringing the Messiah Through the Law: A Case Study, in Nomos XXX: RELIGION, MORAlity AND THE LAW 201, 202 (J. Pennock \& J. Chapman ed. 1988) [hereinafter Cover, Messiah]. 
world we have to a world we can imagine."40 In this way, the unlawfulness of messianism is reversed. The conditions for a "lawful messianism" become possible. ${ }^{41}$

Set against the backdrop of the law's violence, the danger of a lawful messianism emerges with gripping immediacy. For by integrating the law's messianic possibility with its violent reality, Cover heightens both the law's instability and its violence. Indeed, he may be read as opening the way to unconstrained violence as a way of life. Consider, for example, Cover's closing words in the last law review article that he wrote:

The citizen or dissenter's constitutional interpretation cannot be less the deed than that of the state's officials. If the officials of the state realize their vision in blood, the dissenter must also either suffer or impose a parallel form of violence. Warren Burger and his group may or may not be ready to kill with their own hands. But they are ready to kill. ... If a movement such as the right-to-life movement is to make law, it too must be ready, as it is, to suffer or impose violence for the constitutional vision it develops. In other words, the extension of constitutional politics from argument to action-from briefs to pickets or sit-ins or even bombings-is in part compelled by the logic of constitutional interpretation.

In law to be an interpreter is to be a force, an actor who creates effects even through or in the face of violence. To stop short of suffering or imposing violence is to give law up to those who are willing to so act. The state is organized to overcome scruple and fear. Its officials will so act. All others are mere petitioners if they will not fight back. ${ }^{42}$

There is a logic to Cover's acceptance of violence. As the above quotation plainly shows, following that logic to its natural end leads us to see social violence as a necessary adjunct to meaning's advent in the law. In what follows, I argue that Cover's error in this respect stems, in significant part, from his undaunted faith in the compelling truth of a moment's vision. Put differently, his logic operates within a unique geometry of faith. Presently, I will challenge that faith. First, I want to lay out the interconnected claims that constitute the logic.

Consider the following Coverian propositions: (1) Legal interpretation is at once a creative and a destructive act. As it brings some normative worlds

40. Id. at 201.

41. Id. at 204 ("A lawful messianism entails a special form of commitment that holds to the immediacy of a privileged and strange transformation while insisting on a highly unusual capacity for familiar transformational institutions.").

42. Cover, Bonds, supra note 34, at 832-33 (emphasis in original); cf. Cover, Folktales of Justice: Tales of Jurisdiction, 14 CAP. U.L. REv. 179, 203 (1985) [hereinafter Cover, Folktales] ("Integrity in both kinds of judges [both the utopian jurist and the state's judge] is the act of maintaining the vision that it is only that which redeems which is law."). 
into being, it casts others out. ${ }^{43}$ (2) Commitment to a given interpretationputting one's body on the line-makes law. ${ }^{44}$ (3) Judges have no privileged insights regarding the meaning of a constitutive (or destructive) legal interpretation. ${ }^{45}$ (4) Judicial understandings, embedded in legal narratives, are enacted based on social preconditions, which Cover refers to as the "conditions of effective domination." 46 This means that the parties involved in a given conflict know, as does the judge, that judicial understandings are backed by the coercive force of the state. On this view, contrary to the naive political rhetoric of scholars like Ronald Dworkin and the theoretical coherence of their free-standing (Herculean) textual interpretations, ${ }^{47}$ (5) legal interpretation in reality is not a free act. It is bound (or "bonded") within a triadic "molecular" structure: the word (of interpretive understanding) is made real in the deed (of legal violence) through established institutional structures or roles (of those social agents, from judge to warden, who must participate in the legal system for the word effectively to be made into the deed). 48

If we accept Cover's notions that law is simply a matter of commitment and that judges have no special insight into interpretive meanings, then it follows that law can derive from any interpretive commitment. ${ }^{49}$ Thus, for example, citizen dissenters may make law as readily as judicial decisionmakers-provided that their commitment to a word (or vision or meaning) is backed up by a willingness to achieve its enactment through deeds (of

43. Cover, Nomos, supra note 5, at 15-16.

44. Id. at $44-46$.

45. Id. at 54; Cover, Bonds, supra note 34, at 832.

46. Cover, Bonds, supra note 34, at 820-21.

47. See Cover, Violence, supra note 34, at 1627-28 (the hypothetical world of Herculean interpretation "does not and cannot carry the force of collective violence").

48. Cover, Bonds, supra note 34, at 820-21; Cover, Violence, supra note 34, at 1617-18.

49. See Cover, Folktales, supra note 42, at 182 ("The organized behavior of other groups and the commitments of actors within them have as sound a claim to the word 'law' as does the behavior of state officials."); $c f . i d$. at 181 ("[L]aw is neither to be wholly identified with the understanding of the present state of affairs nor with the imagined alternatives. It is the bridge-the committed social behavior which constitutes the way a group of people will attempt to get from here to there. Law connects 'reality' to alternity constituting a new reality with a bridge built out of committed social behavior." (emphasis in original; footnote omitted)).

Elsewhere, Cover notes that '[ $[\mathrm{t}] \mathrm{he}$ challenge presented by the absence of a single, 'objective' interpretation is ... the need to maintain a sense of legal meaning despite the destruction of any pretense of superiority of one nomos over another." Cover, Nomos, supra note 5, at 44. This understanding brings Cover to a pivotal question: to what extent is coercion "necessary to the maintenance of minimum conditions for the creation of legal meaning in autonomous interpretive communities"? Id. I do not think that Cover adequately resolved this question. At any rate, he left an even larger, and to my mind more crucial, question unasked: How much coercion is necessary from without to maintain the minimum conditions for the creation of a legal meaning that will allow disparate normative communities to flourish peaceably within a broader normative framework? Cover's essentially anarchic approach deprives him of the means to pose, much less to resolve, this question. 
violence)-even if this means directly challenging the power of the state. 50 Resistance to state power reflects the dissenter's defiance of extant conditions of state domination. Cover describes the stories of such defiance with phrases like "redemptive constitutionalism," "[m]essianic immediatism," and "utopian constitutionalism." 51 In short, there is in Cover's works a certain romance to the act of rebellion. Prudence and the rule of ordered liberty would counsel otherwise.

Violence risks radical incoherence, introducing perhaps irretrievable forms of psychosis within, to match the state of warfare without. ${ }^{52}$ For this reason, in contrast to Cover's open-ended approach, I submit that the prospect of violence must be more carefully conditioned. This caution leads us back to what I have referred to as the weak link in Cover's analysis, namely his seemingly undaunted faith in the human ability to maintain a moment of pure meaning ${ }^{53}$ in time as a means of creating law and justifying its violent imposition of order upon a given social reality. I believe Cover's faith in this respect makes him incautious about the consequences of inviting new worlds through law. This is particularly so when the new world is steeped in messianic vision.

According to Cover's post-messianic vision, we are of two worlds: one within time, one without. Each bears (bares) a different source of meaning. On the one hand, meaning may come as messianic irruption: a totality rupturing the complex, multi-threaded fabric of time, as if time itself were at an

50. The traditional retort is exemplified by People v. Chachere, 104 Misc. 2d 521, 524, 428 N.Y.S.2d 781, 783 (Dist. Ct. 1980), where, in response to nuclear power protesters who trespassed upon the property of the Shoreham Nuclear Power Plant, the court stated that "it is well-founded law that a moral conviction, (no matter how strong), without the support of substantive and probative evidence" is insufficient to justify otherwise unlawful conduct. The court went on to observe that "anarchy would prevail" if each of us "could claim justification for criminal acts when we had strong moral convictions that our cause was just." Id.

51. Cover, Bonds, supra note 34, at $832-33$ (on "redemptive constitutionalism"); Cover, Nomos, supra note 5, at 33-35 (same); Cover, Messiah, supra note 39, at 202 (on "Messianic immediatism"); Cover, Nomos, supra note 5, at 37-40 (on "radical" and "utopian constitutionalism"); Cover, Folktales, supra note 42 , at $181-83$ (vigorously asserting the equality of all groups' (including the state's) interpretive commitments).

52. See F. FANON, The WRetched of THE EARTH 203-51 (1963) (describing a variety of mental disorders arising out of the violence that took place in Algeria during French colonial rule).

53. See Cover, Nomos, supra note 5, at 14:

[F]rom the mundane flow of our real commonalities, we may purport to distill some purer essence of unity, to create in our imaginations a nomos completely transparent-built from crystals completely pure. In this transparent nomos, that which must be done, the meaning of that which must be done, and the sources of common commitment to the doing of it stand bare, in need of no explication, no interpretation-obvious at once and to all. As long as it stands revealed, this dazzling clarity of legal meaning can harbor no mere interpretation. The shared sense of a revealed, transparent normative order corresponds to the ideal type of the paideic nomos. (emphases added)

Id. (emphasis added). 
end. ${ }^{54}$ Meanings of such supreme disorder-destructive of time itself-have been called a great order. ${ }^{55}$ One may even call them visions. ${ }^{56}$ Such visions may constitute a way of life. ${ }^{57}$

On the other hand, meanings may also be projected from within mortal time: as an immanent aspiration, an imagined future, a hope, or a longing for perfection. Finite understanding spans the chasm of possibility-from reality, here and now, to worlds we can only imagine. And as our normative reality changes, so too does the normative ideal we creatively project. ${ }^{58}$ This temporal context for meaning's creation reflects the constraints of our timebound existence. It is consonant with what I shall later describe as the existential perspective. I shall argue that by curbing Cover's tendency to romanticize narrative, the existential strains within his pre-messianic writing ${ }^{59}$ can

54. See G. SCholem, MAJOR TRENDS IN JEWISH Mysticism 244-50 (3d rev. ed. 1954) (describing the messianic enthusiasm that swept over many Jewish communities following their expulsion in 1492 from Spain); infra notes 112-131 and accompanying text (on the Safed messianic movement); see also W. BENJAMIN, The Task of the Translator, in Illuminations 80 (1969) ("In this pure language - which no longer means or expresses anything but is, as expressionless and creative Word, that which is meant in all languages-all information, all sense, and all intention finally encounter a stratum in which they are destined to be extinguished."); Cornell, The Poststructuralist Challenge to the Ideal of Community, 8 CARDozo L. Rev. 989, 1021 (1987) ("Derrida appeals to the promise of reconciliation in a messianic tongue as the promise of translations. . . . Derrida is surprisingly sympathetic to Benjamin's assertion that translation is a 'redemptive' task."); id. at 1019 ("Perspectives must be fashioned that displace and estrange the world, reveal it to be, with its rifts and crevices, as indigent and distorted as it will appear one day in the messianic light." (quoting T. Adorno, Minima Moralia: Reflections from Damaged Life 247 (1974))); Soloveitchik, The Lonely Man of Faith, 7 TRADrTION, Summer 1965, at 5, 29-30, 38-40 (contact with God is the law).

55. W. Stevens, Connoisseur of Choos, in The Collected Poems of Wallace Stevens 215 (1954):

A. A violent order is disorder, and

B. A great disorder is an order. These

Two things are one.

Quoted in Cover, Nomos, supra note 5, at 4 (emphasis omitted).

56. Cf. L. RADZINOWICZ, IDEOLOGY AND CRIME 4 (1965) ("[Enlightenment thinkers"] vision of the rights of man and the duties of society was in direct conflict with what they saw around them."); J. SCHUMPETER, THE HISTORY OF ECONOMIC ANALYSIS 41 (1954) ("[A]nalytic effort is of necessity preceded by a preanalytic cognitive act that supplies the raw material for the analytic effort. In this book this preanalytic cognitive act will be called Vision.").

57. Meanings that burst whole through the fragmenting prism of mortal time are the stuff that great social transformations are made of, provided one is willing to commit one's very life to the vision's enactment. Consider Moses' exodus from Egypt, or Paul's break with the old laws on his way to Damascus. Each of these historical movements bears witness to the inspired words of prophets, words that come from some strange, transcendent source. They are words powerful enough to initiate, and perhaps carry through to violent enactment, great social transformations.

58. See Cover, Messiah, supra note 39, at 201-02 ("[A]s our concept of where we are (normatively) changes, so does our concept of the possible world to which our law impels us to go.").

59. See Cover, Nomos, supra note 5, at 45 n.125 (conceding that "commitment" is not the exclusive province of blind enthusiasts; it may be practiced by those cognizant merely of possibilities). 
be used to rescue his understanding of interpretive commitment from the danger of messianic totalitarianism.

According to Cover before his messianic turn, the coherence and compelling narrative force within the works (and the normative worlds) of humanity, the force that binds things together, generates a profoundly paradoxical tension. On the one side is the far shore of vision, a place of meaning pure. On the other lies a more familiar world, a world of forms and constraints, of social structures and violence. ${ }^{60}$

The paradox of our condition and of our works, therefore, can be viewed as the paradox of violence and creation. The paradigm is birth. In this respect, Cover seems to have believed, as Freud did, ${ }^{61}$ that eros (the life force) coexists with thanatos (the death force). In Cover's terms, the structures that are necessary to hold a world (or a life) together, the organizing principles that preserve the coherence and stability of meaning, are themselves incapable of producing meaning. ${ }^{62}$ What they are capable of producing is a violent parturition. To bring a new world (or nomos ${ }^{63}$ ) into being requires that meaning's other possibilities never be born. Thus, Cover says that to maintain a normative world (of law) requires the imperial force ${ }^{64}$ of social order (or control).

Pursuing this dichotomous understanding of meaning's jurisgenerative origin and jurispathic conservation, Cover says that it is "narrative" 65 that gives life to meaning. Social controls, by contrast, kill alternative meanings in or-

60. Cf. V. Turner, Dramas, Fields and Metaphors $45-57$ (1974) (contrasting social structure with communitas ("anti-structure") as constitutive sources of our social reality).

61. See S. Freud, Beyond the Pleasure Principle 46-48, 54 n.1 (J. Strachey trans. 1961).

62. See Cover, Nomos, supra note 5, at 16 (proliferation of meanings creates destructive incoherence without the organizing force of imperial social structure; "an organizing principle itself incapable of producing the normative meaning that is life and growth" must be "unleash[ed] upon the fertile but weakly organized jurisgenerative cells").

63. See id. at 9 (describing a nomos as a "present world constituted by a system of tension between reality and vision"); see also Caputo, supra note 6, at 255 ("[B]ecause man is held in the hold of Being, Being alone issues the true nomos for man, assigning him his essence and true abode" (citing M. Heidegger, A Letter on Humanism, in Martin HeIdegger: Basic Writings 193, 238-39 (1977))). The problem with Heidegger's thinking is that as we wait for Being's call, ethics must be put on hold. This is a criticism to which Heidegger is particularly vulnerable, given his brief but active early political commitment to Nazism). See V. FARIAS, HeIDEGGER AND NAZISM (1989).

64. "Imperial force" refers to the coercive constraints or institutions that are necessary to maintain a social world. See Cover, Nomos, supra note 5, at 13 \& n.36.

65. According to Cover, narratives are "models through which we study and experience transformations that result when a given simplified state of affairs is made to pass through the force field of a similarly simplified set of norms." Id. at 10; see also id. "The codes that relate our normative system to our social constructions of reality and to our visions of what the world might be are narrative."); id. at 45 (" $\mathrm{Th}[\mathrm{e}]$ objectification of the norms to which one is committed frequently, perhaps always, entails a narrative -a story of how the law, now object, came to be, and more importantly, how it came to be ones's own. Narrative is the literary genre for the objectification of value."). 
der to preserve one particular meaning. ${ }^{66}$ In this respect, Cover's analysis calls to mind Durkheim's model of society. Like Durkheim, Cover employs biological metaphors to capture the essence of social life. In place of Durkheim's living social "organism,"67 however, we encounter Cover's "legal DNA," that "seed" of "jurispotent" vision which functions as an "imagined instant of unified meaning." 68 Yet, Cover's is a vision strained with a Darwinian agony: the recognition that life is a battle for conquest amidst violent upsurges. Unlike Darwin, however, Cover strips life of evolutionary progress. For Cover, meaning's violent advent seems to lack any guarantee beyond violent commitment itself as the basis for supremacy. Darwin minus faith in biological evolution: perhaps this is the Coverian formula, a formula reminiscent of Nietzsche's profound pronouncement of the will to power. ${ }^{69}$

According to Cover, the emergence of any social order always contains the seeds of social violence. A meaning unbacked by force is unstable. Coercive social structures preserve particular meanings from the chaotic surge of meaning's abundance..$^{70}$ In this sense, social structure comes to be associated with destruction rather than creation. Indeed, Cover casts judges in the role of "killers" of law's multiple possible meanings. They destroy the "luxuriant growth of a hundred legal traditions" in order to "assert that this one is law."71 If this is so, then to resist the state's imperial force is to side with life over death. Interpretive commitment to an alternative meaning fosters the legal transformative process by which meaning may triumph over power. ${ }^{72}$

Notably, it is the violent ("jurispathic") aspect of legal order that leads Cover in his mature but pre-messianic work to view law as that which holds

66. See id. at 11 (referring to the dichotomy between "a social basis for jurisgenesis and a corresponding social basis for the process that destroys legal meaning in the interest of social control").

67. See E. Durkheim, Sociology and Philosophy 1-10 (1974).

68. Cover, Nomos, supra note 5 , at 15.

69. Cf. S. LeviNson, supra note 5, at 174-75 (asserting that at "the very least" there are "no selfevident, immutable, or eternal truths" and that this not only places many of our values "up for grabs," it also renders "ever more problematic" the basis upon which a particular value should be chosen). Levinson concludes that all he can endorse is sincere conversation and a commitment to back morality over positive law when it seems right to do so.

70. Cover, Nomos, supra note 5, at 16 (because of the "multiplicity of meaning-the fact that never only one but always many worlds are created by the too fertile forces of jurisgenesis," coercive social institutions are necessary to maintain a particular normative world of meaning).

71. Id. at 53 (emphasis in original).

72. Cf. id. at $52-53$ (noting that resistance to state power is an option that always remains a part of our reality).

The dichotomization of meaning and power is a key element in Cover's pre-messianic anarchic vision. Minimizing the state and its imperial jurispathic structures is a way of maximizing the multiplicity of meaning. This vision is quite close to the one that inspires Roberto Unger. See R. UNGeR, FALSE NECESSITY 279-80 (1987) (championing disentrenchment or plasticity, which Unger also refers to as "trashing the script," in order to break with the "tedious, degrading rhythm of history" and with "narcoleptic routines"); $c f$. P. BERGER, supra note 5, at 89-101 (on legitimizing dealienation). 
reality and vision apart, as that which rescues us from eschatology. ${ }^{73}$ Put differently, our awareness of a particular meaning's temporal contingency leads us to resist its finality. By reminding us of the imperial force that empowers a particular community's interpretive commitment to a contingent meaning, Cover sensitizes us to interpretive conceit. That conceit consists in the denial of contingency and of meaning's compromise with violence. It is, in short, a denial of meaning's impurity. Thus, given the incessant and varying possibilities that other jurisgenerative moments may yet unfold in time, to totalize commitment to a momentary meaning seems to risk finalizing the fragmentary.

With this insight into the paradoxical tension that simultaneously constitutes law's meaning and law's order, ${ }^{74}$ we may also better understand Cover's urging us to "stop circumscribing the nomos" and "invite new worlds."75 For on this view we see that the boundary by which we mark off one particular world of meaning from another is but an imaginary line-a matter of coercively and falsely denying meaning's endlessly creative flow. Reifying that line may be likened to a child's clinging to a favorite tale. ${ }^{76}$ Yet, the demarcations of legal meaning that social structures define are no mere children's tales. For the tales of the law are held fast by the imperial force of the state. These are narratives written in blood; they are inscribed in the field of law's effective enactment, which is a field of pain and death. Thus, Cover's pre-messianic message clearly emerges: let the creative process surge-and let the state stand back from legitimating (or delegitimating) one world (nomos) rather than another. ${ }^{77}$

According to Cover, redemptive movements seek release from the bonds created by a given social order. ${ }^{78}$ These movements remind us that the social order is but a reification of a time-framed moment of vision. Backed by a force of their own, discrete countermovements make their own law-in

73. See Cover, Nomos, supra note 5 , at 10.

74. See id. at 18 (noting that "there is a radical dichotomy between the social organization of law as power and the organization of law as meaning").

75. Id. at 68.

76. See P. Berger \& T. Luckmann, The Social Construction of Reality 82 (1966) ("Reification is the apprehension of human phenomena as if they were things, that is, in non-human or possibly suprahuman terms. ... Reification implies that man is capable of forgetting his own authorship of the human world, and further, that the dialectic between man, the producer, and his products is lost to consciousness.").

77. The problem that Cover fails adequately to address is what level of coercive force must be maintained to mediate multiple normative realities. See supra note 49; cf. Cover, Nomos, supra note 5 , at 44-60 (addressing question of intra-community rather than inter-community coherence). In this respect, his vision of pluralism is much more in line with the Supreme Court's post-Lemon (and Michael Perry's) picture of peaceful co-existence among conflicting normative claims than with Justice Black's more historically sensitive, and in my view more accurate, picture of inter-factional strife. See infra note 165 and supra note 4.

78. See Cover, Nomos, supra note 5, at 33-35. 
blood, if need be. Their violence is the violence of birth, a new fruition of the life-force that flows in every strand of legal DNA. As Cover says, the life of the law is an endless mitosis; a proliferation of discrete orders, or meanings, or narratives-each binding in timely exile a momentary vision of what life might be. ${ }^{79}$ In an affirmative sense, the gap between meaning's endless provenance and order's deadly constraint represents the open space into which creative transformations can be driven. At the same time, however, the gap also reminds us of the conceit that lies within any interpretive commitment from its inception.

To the extent that Cover understood the fictions of the law, the violence of commitment that is the law's life-blood, and the paradoxical and ultimately precarious basis for the generation and conservation of any normative world, it is understandable that he would view law as a bridge which holds reality and vision apart, as that which rescues us from eschatology. While vision may imply change, eschatology covets finality. Unrescued from eschatology, we have no way of remaining open to the possibilities of new worlds. Eschatology tells us of ultimate union. It tells of time's end. Once the imaginary line separating one world from another dissolves, the imperial order of social structure dissolves along with it. With time's end, mortal fictions also end. The eschatological telos is the totalization of vision and reality, of meaning and power. The telos is the supreme union, the supreme authority. It leaves room for nothing else.

\section{Stating A Messianic Vision: The Totalitarian Shadow}

Notwithstanding his earlier recognition of the conceit by which meanings are totalized, in his final, tantalizingly incomplete essay, ${ }^{80}$ Cover seems to have shifted away from a skeptical view of the telos. Now law comes to be viewed as that which connects vision and reality. ${ }^{81}$ Apparently, at this final stage in his thinking, Cover no longer wished to be rescued from eschatology. Indeed, the antinomian character of messianism is now regarded as an "obvious fallac[y]." 22 The reasons for its obviousness are never explicitly stated. Yet, the fact remains that at this point in his life Cover viewed messianic immediatism as a real possibility. Moreover, in addition to the violence of interpretive commitment, Cover now also speaks of the madness of commitment. In madness lies an alternative means of creating law or of realizing a

79. See id. at 15-16, 31.

80. Cover, Messiah, supra note 39.

81. Id. at 201-02; $c f$. C. GeERTZ, The INTERPRETATION OF Cultures 205 (1973) (asserting that "ideology [playing the role Cover allots to "vision"] bridges the emotional gap between things as they are and as one would have them be").

82. Cover, Messiah, supra note 39, at 202. 


\section{new world. ${ }^{83}$}

Significantly, Cover had often spoken passionately of the prophet's role in society. ${ }^{84}$ Unlike the deferential judge, who bows and winks before the dominance of the state, the prophet, according to Cover, speaks truth (or law) to power. ${ }^{85}$ Prudential deference to state power is, in Cover's words, the final sin of judging. ${ }^{86}$ But if interpretation is the source of discrete meanings, as it is of the word's (violent) deed which the legal system must effectively enact, may we not then properly inquire: What is the word that the judge is to interpret in order to speak truth? If it is a text, as Cover suggests it is, ${ }^{87}$ what kind of text? What are the criteria for its selection and contextual application? And by what criteria is its interpretation to be assessed? Put simply, how are we to know whether the truth has in fact been spoken?

Cover's confident assertion that truth can and must be spoken to power reflects his deep faith in the compelling truth of a meaning's advent in time. His is the faith of the natural law jurist, whose heroes-Antigone, Simeon $b$. Shetah, the American revolutionaries, the antebellum abolitionist leaders ${ }^{88}$ perform the special office of judge as prophet. ${ }^{89}$ Theirs is the vision of a justice supreme; theirs is the universal higher law. The authority that inspires their commitment is the sacred text: whether it is the unwritten text of nature (as it was for Antigone) or the word of God (as was the case for many of the abolitionists). The sacred text is the compelling narrative, which Cover describes as the originating source of meaning. Commitment to it will not only generate the law, it might also generate a new normative world. What is the sacred text that authorizes the genesis of law? For Cover, the answer seems to be this: it is precisely that text which will generate commitment-in blood, if need be. As he puts it: "[T]he romance of the deed trans-

83. See id. at 204. Of course, "madness" can always be turned around. See F. BAcoN, supra note 4, at 11 ("If an heathen come in, and hear you speak with several tongues, will he not say that you are mad?" (emphasis in original)); see also E. GRASSI \& M. LORCH, FOLIY AND INSANITY IN RENAISSANCE LITERATURE 49-63 (1986) (treating Erasmus' In Praise of Folly as a serious, rather than satirical, assessment of moria (religious folly); E. GRASSI, supra note 10, at 90 (see quoted material at note 10 ).

84. See R. COVER, Justice ACCuSEd 149-58, 259 (1975); Cover, Folktales, supra note 43, at 189-90.

85. Cover uses the term "law" interchangeably with "truth" in describing acts in defiance of "power." See Cover, Folktales, supra note 42, at 190.

86. See id. at 190.

87. See Cover, Nomos, supra, note 5, at 4 ("No set of legal institutions or prescriptions exists apart from the narratives that locate it and give it meaning. For every constitution there is an epic, for each decalogue a scripture.").

88. See Cover, Folktales, supra note 42, at 184 (tale of Simon b. Shetah); Cover, Nomos, supra note 5, at 35-40 (sketching two strains of anti-slavery constitutionalism).

89. See R. Cover, supra note 84 , at 259; Cover, Folktales, supra note 42, at 189 ("As a judge, one must be other than the King ... because of the need to institutionalize the office of the Prophet ...."). 
forms the interpretation of the dissenting community into a species of true constitutionalism." 90

In this respect, I believe Cover may be criticized above all for his tendency to idealize narrative itself. ${ }^{91}$ For example, in his description of the creative (jurisgenerative) and destructive (jurispathic) aspects of a legal meaning's existence, Cover explicitly dichotomizes power and meaning. ${ }^{92}$ It is as if violence curved around meaning-holding it apart from extraneous, tainting forces. Narrative truth thus obtains a kind of crystalline purity, while imperial principles of order provide structure from without. But this bifurcation of meaning (narrative) and structure (the imperial force of social constraint) is itself a curious fiction. ${ }^{93}$ For so long as meaning occurs in language, it is difficult to see how the contingency ${ }^{94}$ of social structure can ever be separated out. This claim requires elucidation. Such a task, however, is fraught with difficulties. For how can one hope to make sense in language of the way meaning occurs in language?95 Doesn't this entail speaking of (or from?) that which lies outside speech (meaning's inchoate source)? ${ }^{96}$ To risk speech

90. Cover, Bonds, supra note 34, at 832; cf. Cover, Nomos, supra note 5, at 51 ("Violence at the hands of the state escalates the stakes of the interpretive enterprise, but so does the violence of any nonstate community in defining its bounds or implementing its redemptive program." (footnote omitted)).

91. For additional grounds for criticism, see infra text accompanying notes 195-203 (noting that by his failure to distinguish between extralegal and legal sources of authority, Cover derogates from the foundational authority of the federal Constitution-a text which plainly states that it shall be the supreme law of the land). This additional criticism addresses Cover's failure adequately to account for the legal encumbrance of the Constitution as the price we pay for (at least part of) our self and social identity. See C. GEERTZ, supra note 81, at 33-54 (on the cultural-linguistic contextualization of self and community); M. SANDEL, LIBERALISM AND THE LIMITS OF JUSTICE 179-83 (1982) (on the encumbered self).

For other grounds of criticism, see infra text accompanying notes 204-207 (noting that Cover's suggestion that the federal constitutional narrative may be supplanted by any number of alternative texts undercuts the very source of authority that empowers and legitimates the court's-or any other governmental or nongovernmental-act of legal interpretation). See also U.S. CoNST. art. II, $\S 1$, cl. 7 (swearing to protect and defend); Ely, The Wages of Crying Wolf: A Comment on Roe v. Wade, 82 YALE L.J. 920, 949 (1973) ("A neutral and durable principle may be a thing of beauty and a joy forever. But if it lacks connection with any value the Constitution marks as special, it is not a constitutional principle and the Court has no business imposing it." (footnote omitted)).

92. See Cover, Nomos, supra note 5 , at 18.

93. In Nomos, his major pre-messianic text, Cover seems willing to recognize that at least "to some extent" the division of meaning and violence is a "fantasy." Id. at 40. His post-messianic works, however, do not reflect such critical self-caution. See Cover, Messiah, supra note 39, at 204 ("Messianism requires a commitment that entails loss of present social life, authority, and reality in exchange for that which can only be imagined.").

94. Used in both the adjectival sense of "circumstantial" and the nominal sense of "representative group."

95. Cf. Cornell, supra note 10, at 177 ("[T]he very entertainment of sittlich commitments in language denies those commitments the structure of a self-denial form. . . . [L]anguage cannot be elevated to its concept.").

96. See Seery, Politics As Ironic Community, 16 PoL. TheORY 229, 240 (1988): 
here, we must enter the realm of irony. The strange drawing power of figurative speech and conceptual abstraction will need to be consciously confronted. In what follows, then, we will proceed on the sly, so to speak. Indeed, the irony lies in our consciousness of this discursive constraint.

\section{Between Faith AND Power: Stating A World of Discourse UNDER LAW}

Let us start with an image: language is the prism of our being in time; it fragments Being (the undifferentiated unsaid) into discrete forms (of meaning). ${ }^{97}$ In our forgetfulness of the conceit of language-namely, that its forms and meanings are contemporary and contingent-lies our forgetfulness of the difference between particular meanings and their originating (chaotic, and thus unutterable) source. ${ }^{98}$ With the aid of language, we struggle to contain the staggering fecundity of meaning, for only within language can we (temporarily) limit the bewildering multiplicity of meaning's figurative and conceptual possibilities. ${ }^{99}$

Thus, in contrast to Cover's bifurcation of pure, instantaneous meaning

Plato's self-parody, his irony, is an indication to the reader of Plato's own awareness of his art as art. ... [T] [Te point seems to be to invite the reader to question the text for himself or herself, to regard the words as aspects of representative art, and as art, to realize the book's inadequacies, namely that what Plato is trying to convey goes beyond (overlook the visual imagery) what is literally represented.

See also S. KIERKEgAARD, The CONCEPT OF IRONY 236, 339 (1965):

Irony, like the Law, is a demand; indeed, irony is an enormous demand, for it disdains reality and demands ideality. ...

... He who does not understand irony and has no ear for its whisperings lacks eo ipso what might be called the absolute beginning of the personal life. He lacks what at moments is indispensable for the personal life, lacks the bath of regeneration and rejuvenation, the cleansing baptism of irony that redeems the soul from having its life in finitude though living boldly and energetically in finitude. He does not know the invigoration and fortification which, should the atmosphere become too oppressive, comes from lifting oneself up and plunging into the ocean of irony, not in order to remain there, of course, but healthily, gladly, lightly to clad oneself again.

97. Cf. M. HeIDEgGer, The Nature of Language, in ON THE WAY To LANGUAGE 57, 63 (1971) ("The being of anything that is resides in the word. Therefore this statement holds true: Language is the house of Being.").

98. See id. at 59 ("Curiously enough, when we cannot find the right word for something that concerns us, carries us away, oppresses or encourages us. Then we leave unspoken what we have in mind and, without rightly giving it thought, undergo moments in which language itself has distantly and fleetingly touched us with its essential being."); J. DERRIDA, White Mythology: Metaphor in the Text of Philosophy, in MARGINS of PHILOsophy 207, 233 (1982) ("Thought stumbles upon metaphor, or metaphor falls to thought at the moment when meaning attempts to emerge from itself in order to be stated, enunciated, brought to the light of language.").

99. See M. Foucault, The Discourse on Language, in The Archaeology of KNowledge 224 (1972) ("We tend to see, in an author's fertility, in the multiplicity of commentaries and in the development of a discipline so many infinite resources available for the creation of discourse. Perhaps so, but they are nonetheless principles of constraint, and it is probably impossible to appreciate 
and coercive, jurispathic social structure, I submit that every meaning contains within it the contingency and deceit of social structure. ${ }^{100}$ Put differently, within the realm of human history and understanding, a decontextualized (or ahistorical) utterance is unthinkable. ${ }^{101}$ On this view, then, the deceit (or "made-up" aspect) of meaning 102 and its conceit (viz. the denial of partiality) are present in discourse even when interpretation falls short of coercive (or imperial) enactment.

If this is so, then the totalization of any meaning cannot but also reflect the totalization of its deceit. ${ }^{103}$ Yet, it is precisely Cover's separation of meaning and social structure that allows us to forget this danger. ${ }^{104}$ In short, forgetfulness of meaning's deceit is precisely the error that opens up the possibility of its totalization. ${ }^{105}$ And it is here that Cover's pre-messianic anarchic embrace of multiple normative worlds begins to slip into messianic belief, and the totalizing embrace of redemption.

As long as Cover refrained from privileging a particular normative world, which is to say, as long as he described the creative and destructive aspects of legal meaning from a position outside any particular system of belief, his invitation to let new worlds surge forth could be held open. For this is an invitation inspired by anarchic joy in the creative process itself. ${ }^{106}$ But when belief

their positive, multiplicatory role without first taking into consideration their restrictive, constraining role.").

100. As Cardozo realized, language proceeds by way of an incessant oscillation between figurative utterance and its deadening reification. See Berkey v. Third Avenue Ry., 244 N.Y. 84, 94,155 N.E.2d 58, 61 (1926) (Cardozo, J.) (the metaphor begins by freeing thought, but ends by enchaining it). Interestingly, most commentators seem content to focus upon the latter rather than the former part of this statement. Is this because they unwittingly presume that the standpoint from which the deadened metaphor is revealed is itself immune to death?

101. Note, for example, Wittgenstein's shift from the Tractatus (analytically stating everything that is the case) to his Philosophical Investigations (where meanings emerge as the byproduct of discrete language games). Compare L. Wittgenstein, Tractatus Logico Philosophicus (1960) with L. WitTGensteIn, THe PhILosophiCAI INVEstigations (1966). Also relevant is Aristotle's observation that the dialectical discourse of natural science is inappropriate to the study of human history and understanding; for the latter we have rhetorical discourse, where only probabilities, not certainties, are available. ARISTOTLE, RHETORIC 22 (1954); $c f$. H. GADAMER, TRUTH AND METHOD 21-33 (1982) (contrasting scientific Cartesian or theoretical universalistic knowledge with the concretely contextualized (historical) knowledge of practical reason or phronesis).

102. Fiction qua fict-io.

103. To capture the flavor of totalized (or absolutely conceited) deceit, one might coin the term "condeception."

104. See, e.g., Cover, Nomos, supra note 5, at 9-11. Notwithstanding Cover's description of the so-called "paideic" community in pre- or non-statist terms, it is notable that even a community such as this cannot escape the coercive ramifications of power and social structure with respect to that community's relations with other communities.

105. Put differently, the con (of figurative utterance) invites the conceit (of conceptualization).

106. See supra note 10 (for illustrations of anarchic inspiration); $c f$. E. GRASSI \& M. LORCH, supra 83, at 95-96 ("The blissfulness which characterizes the human comedy is not attributed to the divine, that is, to the 'new' that resides 'over' and 'above' human history (and therefore transcends 
is captured by a particular "purified" meaning, anarchic joy may give way to a different bliss. I suspect that it is this shift, from detached joy to messianic commitment, that marks Cover's changed attitude toward the telos. And the consequences are quite serious. Once law is viewed as capable of bringing the Messiah, once it becomes a bridge of redemption - the very avenue of messianic immediatism that connects reality with a particular privileged vision-is not Cover's previous invitation to multiple worlds rescinded? What meaning can follow upon time's end? Put differently, what does an "alternative" meaning look like (much less the process of meaning's creative surging forth) when viewed from within the messianic telos itself? ${ }^{107}$ Beyond the meanings in which we believe there lies babble.

On this analysis, then, Cover's turn toward messianic immediatism may be viewed as an outgrowth and intensification of his earlier faith in the advent of meaning untainted by force or structure. 108 Put differently, it is an act of faith that capitalizes on his earlier romanticization of narrative in that it not only insists upon a clean cleavage between (emancipatory) meaning and (imperial) order, but now also allows for the privileging of one such meaning above others.

In two late essays, ${ }^{109}$ Cover claimed to have identified a specific historical case study for his vision of the law as connective bridge. The case study in question recounts an attempt in 1538 to create a court that would bring the Messiah to the Holy Land. ${ }^{110}$ The significance for Cover of this creation of "true jurisdiction"111 stems from the putatively legal basis that was claimed for it. According to Jewish law, "ordination" or semikhah, the laying on of hands, represents the direct and uninterrupted transference of authority from Moses on in history to properly ordained judges. ${ }^{112}$ At some point in the

it): it may be found only by abandoning yourself totally to the appeal of 'moria' [or "folly", or "physis"-the burgeoning forth of being], which is experienced in history . ...").

107. For perspectives within a messianic belief system, see S. HAUERWAS, supra note 4 (on the indubitability of Christian truth); F. ROSENZWEIG, THE STAR OF REDEMPTION (2d ed. 1930) (on Judaic truth).

108. See supra notes $87-89 \& 94$ and accompanying text. One might add that it also represents an intensified gesture of dissatisfaction with the world as it is.

109. Cover, Folktales, supra note 42; Cover, Messiah, supra note 39.

110. Cover, Folktales, supra note 42, at 191-97; Cover, Messiah, supra note 39 at 204-10.

111. Cover, Folktales, supra note 42 , at 194.

112. See R. WerblowsKi, Joseph J. CARO: LAWYER AND MYSTIC 122 (1962):

According to rabbinic halakhah [law] . . . knowledge of the law is not sufficient to administer it. The jurist has to be invested with due authority, in virtue of which his power formally derives from the ultimate source of sovereignty recognized by his society. Jewish law had evolved the notion of a kind of 'apostolic' succession beginning with Moses, who was invested by God himself and who subsequently laid his hands on Joshua. Every ordained 'judge' could pass on ordination to others, and only ordained judges could constitute a 'Synhedrion' or any other kind of valid court.

See also Numbers 11:25 ("The Lord then came down in the cloud and spoke to [Moses]. Taking 
early Middle Ages, this chain of authority was broken. ${ }^{113}$ However, following the catastrophic exile of the Jews from Spain in 1492, a wave of messianic anticipation swept over the scattered Jewish community. This new enthusiasm was felt especially among the most pious of the Jewish refugees, who believed that history was about to come to an end.114 Jewish scholars now turned their attention to the first chapter of $I_{\text {saiah }} ;^{115}$ for this text was interpreted as holding that when the original authority of ordination was re-established, the Messiah would come. ${ }^{116}$

The legal question that had to be resolved was this: How does one restore ordination (or semikhah) once it has been broken?117 The "sacred tale" that Cover recounts of the rabbis of Safed tells of one daring response. In Safed, a small city in the Galilee, a group of twenty-five rabbis, led by Rabbi Jacob Berab, unanimously appointed Berab to be given semikhah.118 In this way, that is, by restoring the link to the truly ordained judges of old, the messianic prophecy of Isaiah was to have been fulfilled in practice.

The rabbis of Safed immediately announced to the sages of Jerusalem the news of their restoration of semikhah. In doing this, they were following the authority of Maimonides, who wrote in the Mishneh Torah in 1180 that the consent of all the sages in Israel was necessary to achieve the renewal of true ordination. ${ }^{119}$ The actual text of the Safed rabbis' proclamation was a dense scholarly interweaving of biblical excerpts. ${ }^{120}$ These fragments of traditional text, synthesized in a novel interpretive structure, generated a new text in its own right. According to Cover, with this textual creation the Safed rabbis sought to create a link-and to allow a crossing over-from present reality to the final, time-ending telos of redemption. ${ }^{121}$

For Cover, the Safed rabbis" proclamation "evince[s] not only dramatic

some of the Spirit that was on Moses, he bestowed it on the Seventy elders; and as the Spirit came to rest on them they prophesied.").

113. R. WERBLOWSKI, supra note 110, at 123.

114. See G. SCHOLEM, supra note 54, at 246-47 ("For the exiles from Spain the catastrophical character of the 'End' was again made clear. To summon up and to release all the forces capable of hastening the 'End,' became once more the chief aim of the mystics. . . . The birthpangs of the Messianic era, with which history is to 'end' or (as the apocalyptics would have it) to 'collapse,' were therefore assumed to have set in with the Expulsion."); 11 ENCYCLOPAEDIA JUDAICA 1418 (1972) ("One element basic to Jewish messianism is anticipation of the "birth pangs of the Messiah" ... the time of troubles and turbulence that precedes his coming.").

115. Isaiah 1:26 states: "I will restore thy Judges as at the first . . . [a]fterward thou shalt be called [t]he city of righteousness, [t]he faithful city."

116. Cover, Folktales, supra note 42, at 193.

117. Id.

118. Id. at 195; 14 ENCYCLOPAEDiA JudAiCA 1144 (1972).

119. See Cover, Folktales, supra note 42, at 193-95.

120. See Cover, Messiah, supra note 39, at 210-15.

121. See Cover, Folktales, supra note 42, at 194 (for the Safed rabbis, "'true jurisdiction' was a sacred aspiration, a part of Messianic fulfillment"). 
dissatisfaction with the world as it is, but a looming responsibility for drastic change."122 It is an example of "committed practical behavior"123 that seeks to establish a "lawful messianism." 124 Yet the question remains: What is the lesson Cover would have us learn from this case study in messianism? What is his "strong claim ... for the teleology implicit in law"?125 What does it mean that the law, rather than rescuing us from eschatology, is now viewed as capable of fulfilling the messianic telos? ${ }^{126}$

Unfortunately, Cover's untimely death left the last section of his final essay on the Safed movement unwritten and cut short further exploration of these issues. Nevertheless, we can still try to piece together some of the clues that Cover has left us. For example, consider what may be his final essay's most tantalizing and suggestive sentence: "A lawful messianism entails a special form of commitment that holds to the immediacy of a privileged and strange transformation while insisting on a highly unusual capacity for familiar transformational institutions."127 Employing Coverian terms, we might translate the Safed rabbis' messianic proclamation this way: Held apart from any form of social dominance-indeed, risking madness in rebellion against the actuality of a particular time and place-the Safed rabbis produced a crystal of pure meaning. ${ }^{128}$ Their text of natural jurisdiction represented a redemptive constitution on the basis of which they proclaimed a lawful messianism. Their action also "insist[ed] on an unusual capacity for familiar transformational institutions," 129 for they proclaimed natural jurisdiction for messianic immediatism through already existing texts, using familiar hermeneutic methods. What is more, their proclamation was followed by efforts to obtain acceptance from recognized officials. ${ }^{130}$

In other words, this historical illustration of lawful messianism is not only consonant with Cover's earlier understanding of law as interpretive commitment, but it also directly tracks the terms contained in the statement quoted above. The sacred texts of Jewish law, which the Safed rabbis newly construed, inspired "a special form of commitment." This commitment proclaimed "the immediacy of a privileged and strange transformation": namely, the fulfillment of messianic longing. Moreover, in the familiar her-

122. Id. at 197.

123. Id.

124. See Cover, Messiah, supra note 39, at 204.

125. $I d$. at 202 (emphasis in original).

126. See id. at 202-04 (emphasis added).

127. Id. at 204.

128. See Cover, Nomos, supra note 5, at 14 (putting forth the vision of "a nomos completely transparent-built from crystals completely pure").

129. Cover, Messiah, supra note 39, at 204.

130. See Cover, Folktales, supra note 42, at $195-96$ (describing efforts by the rabbis of Safed to obtain agreement with their proclamation from the sages of Jerusalem); 14 ENCYCLOPAEDIA JUDAICA 1144 (1972) (same). 
meneutics of textual exegesis and the search for legitimacy through institutionalized consensus, the Safed rabbis insisted on a "capacity for familiar transformational institutions."

As a matter of history, we know that the Safed proclamation of natural jurisdiction failed. The Jerusalem rabbis refused to go along. ${ }^{131}$ But the lesson, for Cover, remains intact. The story of the Safed proclamation may be read as a tale of the law as bridge connecting (and thus transforming) historical reality with messianic vision. As for the analogy Cover may have had in mind between the Safed messianic movement and the possibilities of constitutional redemption within our legal culture today, we can only speculate. Are the fragments of our constitutional texts and their textual interpretations like the authoritative texts and interpretations that informed and inspired the Safed rabbis? Does the Supreme Court (or perhaps some other interpretive agency, such as the legislature, the executive, or the People) represent a familiar transformational institution akin to the Jerusalem rabbis?

Perhaps. Yet, there remains this unmistakable distinction: Safed textual sources and institutions co-existed within an insular, coherent normative reality. ${ }^{132}$ It is a reality constituted by traditionally accepted sacred textsnamely, the Torah and the commentaries that make up the Judaic belief system. Cover's earlier invitation to let multiple normative realities thrive without governmental constraint suggests that our current culture cannot accurately be described as embodying a similarly coherent tradition. Indeed, a "tradition" of co-equally legitimate value systems is hard to grasp. (Is it possible to speak meaningfully of a "tradition" of disruption and discontinuity?) Cover is in fact quite explicit on this point: "American political life no longer occurs within a public space dominated by common mythologies and rites and occupied by neighbors and kin." 133 And even without the disintegrating force of Cover's earlier anarchic ("polynomial") vision, the much dis-

131. Cover, Folktales, supra note 42, at 196; 14 ENCYClopaEdia JudaiCA 1144 (1972).

According to Cover, the Safed rabbis' practical failure resulted in the kabbalists' mystical interiorization of messianic longing. Cover, Messiah, supra note 39, at 209-10. Cover appears to regret this "esoteric" and "psychological" turn, in that it represents a movement which cannot bring the Messiah "through law." See id. at 210. It may warrant noting, however, that scholars have linked Rabbi Berab's (and Karo's) proclamation of semikhah directly to their earlier immersion in kabbal* istic studies. See 4 EncyClopaEdia JudaICA 583 (1972) ("Berab was swept along with the messianic current of the early $16 \mathrm{th}$ century, which resulted in large measure from intensive study of the kabballah. Berab himself gave some impetus to messianic anticipation by trying to revive the institution of semikhah ....").

In other words, to the extent Cover intimates that the Safed rabbis' attempt at practical ("legal") transformation is separable from esoteric ("illegal") mysticism, this suggestion would seem to be inaccurate, given that mysticism in fact inspired their "practice."

132. To paraphrase Bacon: there may be variety in the garment, but the cloth is of one piece. See F. BACON, supra note 4 , at 12.

133. Cover, Nomos, supra note 5, at 49. While Cover goes on to suggest that "[0]ther bases are necessary to support the common life that generates legal traditions," id., he offers no suggestion as 
cussed absence of any coherent, overarching interpretive system within the current culture seems to confirm the point. ${ }^{134}$

From this posture, then, the meaning of the Safed folktale within our own legal culture (as a parable of constitutional redemption) remains problematic. Indeed, in the face of our current cultural fragmentation it would seem that the source of redemptivist unity would need to come from without. And it is precisely this perception of our "need" that gives rise to illiberal sources of belief. There is, however, another interpretation of the Safed tale that can rescue Cover's pre-messianic understanding of law as interpretive commitment from the dangerous consequences of messianic totalitarianism-consequences that a political or legal philosophy of unconstrained commitment inevitably invite. ${ }^{135}$ This interpretation, contrary to Cover's post-messianic viewpoint, strictly maintains the unlawful aspect of messianic immediatism.

The interpretation I propose, rather than focusing upon the Safed rabbis' proclamation itself, takes for its paradigm the example of Joseph Karo. Rabbi Karo of Safed was part of the academy of scholars that sought to reestablish the natural jurisdiction that would lead to redemption. Yet, in his later scholarly writing, Karo produced a commentary that accepted without critical gloss a provision that directly conflicted with the authority of the Safed rabbis' defiant act. Of this fact, Cover notes: "It is almost as if Karo managed to keep his legalistic oeuvre mentally separated from this act

to the source or identity of such a shared base. In contrast, the dialogic ideal for which I am arguing here would constitute such a base.

134. See, e.g., S. LEVINSON, supra note 5, at 15 (referring to works depicting the Constitution as a source not of unity, but "of fragmentation and disintegration" (emphasis in original)); A. MACINTYRE, AFTER VIRTUE 262 (1984) ("For I too not only take it that Marxism is exhausted as a political tradition ... but I [also] believe that this exhaustion is shared by every other political tradition within our culture." (emphasis omitted)); M. PERRY, THE CONSTITUTION, THE COURTS AND HUMAN RIGHTS 93 (1982) ("There is no single, predominant American tradition-none so determinate, at any rate, as to be of much help in resolving the particular human rights conflicts that have come before the Court in the modern period and that are likely to come before it in the foreseeable future.").

Contrary to these views, I maintain (along with Rawls) that by reaffirming a shared political conception, such as the dialogic ideal of mutually respectful discourse, a unifying force in contemporary legal theory and practice may be claimed. This shared normative ideal may also in turn serve as an interpretive key for reading the history of our political and legal institutions. See Rawls, supra note 28, at 242-43 ("As a form of political liberalism, then, justice as fairness holds that, with regard to the constitutional essentials, and given the existence of a reasonably well-ordered constitutional regime, the family of very great political values expressed by its principles and ideals normally will have sufficient weight to override all other values that may come into contact with them."); $c f$. Cornell, Institutionalization, supra note 14, at 1216 (the "conversion principle ... not only recalls the past as it remembers the future, but also projects forward as an ideal the very principle it reads into the past").

135. It may be worth recalling here that it is in the arena of law and politics, where belief ineluctably intermingles with power, that my critique is meant to apply. In the private realm of conscience, where belief does not seek political or legal enforcement, liberal constraints upon belief need not apply. 


\section{..."136 And that is precisely the point.}

The paradigm of Rabbi Karo, I submit, is this: In an act of faith, he dared to hasten the Messiah's coming; ${ }^{137}$ in a professional act of legal interpretation, he allowed the messianic moment to be kept apart from reality. ${ }^{138}$ While it is unclear whether the post-messianic Cover would accept this distinction between an "act of faith" and "legal interpretation," I believe just such a distinction is crucial for those who are entrusted to make law, and for those who are asked to accept the legitimacy of the law's violence. ${ }^{139}$ Put simply, I submit that the Jerusalem rabbis who rejected the Safed rabbis' authority to proclaim redemptive fulfillment were right. Even assuming we could identify within our own legal culture the kind of "familiar transformational institution" that the Jerusalem authorities may have embodied, messianic belief would still warrant censure. For such belief cannot sustain a lawful claim to state power. ${ }^{140}$

The Jerusalem rabbis' repudiation of the Safed rabbis' messianic proclamation can be viewed as the correct response to any claim that seeks to legalize prophecy. ${ }^{141}$ It is a response that can be explained and justified by reference

136. See R. WERBLOWSKI, supra note 112, at 124-25:

Reading Joseph Karo's utterances on the subject in his halakhic writings, one would never guess that he was personally involved in this 'messianic' enterprise .... In his commentary Kesef Mishneh on the Code of Maimonides ... he does not breathe a single word of approval, and in his [Beth Yosef] he mentions only once and by the way the possibility that 'according to the view of Maimonides ordained rabbis would be thinkable even today.' Elsewhere he takes it for granted that 'nowadays there are no ordained courts.'

Id. (footnotes omitted). In contrast to his "secular" writings, Karo's mystical diaries (the so-called Maggid Mesharim) speak in a different voice entirely. There Karo's words (by a purely transcendental reference) "tell him" that he will be a great leader over Israel and that his sons will be members of the Sanhedrin (Great Court). As Werblowsky points out, whether consciously or not, this text conveys Karo's messianic hopes, along with his rather lofty projection of his own role in ensuring that the tradition of semikhah be finally reestablished-with himself, rather than Rabbi Berab, as the first unanimously appointed, and thus truly ordained, judge. See id. at 125-28.

137. Cover, Messiah, supra note 39, at 209.

138. Cf. R. WERBLowSKI, supra note 112, at 3 ("For more than forty years the activity of Karo's 'mind was divided between dry rabbinical learning and the fantastic [ideas of the] Kabbalah.'" (footnote omitted)).

139. Indeed, it is precisely by their acceptance that legitimacy is obtained. See Rawls, supra note 13, at 223 (explaining that "so far as possible," a public conception of justice in constitutional democracy should be independent of controversial religious and philosophical doctrines); Sherwin, supra note 13, at 407-10 (legitimation of the imposition of ultimate values demands more than internal belief; legitimation "is rooted in a shared consensus among citizens").

140. Similarly, while sectarian abolitionists may provide a valuable contribution to our culture in general, their beliefs cannot sustain a "lawful" claim to state power. See infra PART V; $c f$. Luban, Difference Made Legal: The Court and Dr. King, 87 MiCH. L. REv. 2152, 2187-2210 (1989) (distinguishing the theological from the political, legal, and other non-sectarian narrative sources upon which Martin Luther King relied in his efforts to advance civil rights).

141. I do not pretend to speak here for the Jerusalem sages or to duplicate in any way the reasons that justified their judgment. Suffice it to say, however, that their judgment regarding the illegality of the Safed proclamation of semikhah has been accepted by modern scholars as correct. 14 ENCY- 
to the fundamental condition of meaning's paradox: the paradox manifest in the existential predicament of our being in time. Thus, we shall return to Cover's pre-messianic understanding of the law's jurisgenerative and jurispathic tension. But his position will now be recapitulated from an explicitly post-modern perspective. Specifically, I shall utilize insights that originated with the existentialist movement and that have remained influential for phenomenologists and hermeneutic philosophers alike. ${ }^{142} \mathrm{My}$ contention is that the existential perspective saves us from "lawful" messianism and the tyranny of totalized truth. I also maintain that if we can learn from this perspective the heroics of constrained ethical imagination, we will have obtained a theoretical point of departure for the liberal discourse ideal.

In what follows, I wish to make two claims. First, the existential perspective is consonant with Cover's pre-messianic understanding of law as paradox. Second, only by remaining vigilantly aware of our existential predicament can we adequately check the dangerous hubris of utilizing illiberal belief as a basis for creating law.

Earlier on, I criticized Cover's idealization of narrative by using an image of language as the "prism" of our being in time. ${ }^{143}$ It is to that image that the existential viewpoint now beckons our return. But this return will portend a new caution. It will forewarn us of the dangers that attend the unwitting or deceptive legal empowerment of belief's conceit.

\section{A Post-Modernized Liberal Vision: Rhetorical Pluralism AND THE DISCOURSE IDEAL}

According to the existential perspective, we are all tensely drawn between the urge for meaning and the constraint of our finitude. ${ }^{144}$ Our fate is to

CLOPAEDIA JUDAICA 1144 (1972). Perhaps in a correlative (or at least in a cautionary) sense, Michael Perry's talk about judicial "prophecy" may appropriately be received with suspicion. See M. PERRY, supra note 134, at 98 (describing noninterpretive interpretive judicial review of human rights as the "institutionalization of prophecy").

142. See supra note 6.

143. See supra notes $97-105$ and accompanying text.

144. From the works of thinkers like Kierkegaard, Nietzsche, Heidegger, Jaspers, Sartre, and Camus, we have come to see our being in the world as a continuous overcoming of self. According to this view, the person is a creature who stands anxiously between the fear of death and the creative promise of Being, endlessly projecting the possibilities of his finite understanding in time. Human being is a being-there (dasein). Standing within the finite (historically contextualized) horizon of human understanding, the person enters into relation with others or things. That relation can alter the horizon of understanding, but the understanding nevertheless remains within some localized context. Compare H. Gadamer, Philosophical Hermeneutics 33 (1976) ("Authority is by [Habermas'] definition a dogmatic power. I cannot accept the assertion that reason and authority are abstract antitheses, as the emancipatory Enlightenment did. Rather, I assert that they stand in a basically ambivalent relation, a relation I think should be explored rather than casually accepting the antithesis as a 'fundamental conviction.' ") with J. HABERMAS, COMMUNICATION AND THE EVOLUTION OF SOCIETY 202 (1979) ("[I] philosophical ethics and political theory can know noth- 
creatively project possible worlds within the present horizon of our understanding. ${ }^{145}$ For example, we raise the particular to abstract category through conceptualization, and we relate "this" to "that" fictively through metaphor. By concept and metaphor, we make (up) the meanings by which self, other, and social reality cohere. We believe in these meanings despite their conceits, despite their "fictions." Indeed, we cannot do without such "fictions" (and perhaps for this very reason are inclined to forget their temporal and contingent source).

In short, our understanding of the person and her works-including the law-reflects the fundamental paradox of our being: our very yearning for truth in language ends up enriching the archive of our fictions. This is to be expected. Human works, unredeemed in time, partake of time's fragmentation of Being. Language itself is a prism, it splinters what is, in order to make (up) the discrete meanings that constitute our sense of self, other, and world. ${ }^{146}$ Indeed, upon closer scrutiny we discover that the conceit of language lies in the concept even as it lies in metaphor. ${ }^{147}$

The concept's conceit lies in its raising from concrete particularity to general abstraction some claim to truth. ${ }^{148}$ The fiction of abstractly raising up

ing more than what is anyhow contained in the everyday norm consciousness of different populations ... it cannot then rationally distinguish legitimate from illegitimate domination.").

Gadamer, Habermas, Ricoeur, Foucault, and Derrida, among others, have been playing out the ramifications of the existential shift away from the "scientistic" Cartesianism that culminated in Hegel's Absolute Subject. See, e.g., E. HusSerl, Cartesian Meditations 4-6, 151-57 (1960); Cornell, Institutionalization, supra note 14, at 1144 n.27, 1197-98. Simply put, this means that the traditional location of truth within the subjective knower (i.e., within reason) has moved. It is now thought to occur (rather than await apodictic discovery) between self and other (Buber), self and society (Habermas/Foucault), or self and Being-either in poetic utterance (Heidegger) or in play (Gadamer).

145. See, e.g., P. BERGER, supra note 5, at 81 ("[Humans], collectively, externalize themselves in common activity and thereby produce a human world.").

146. See, e.g., P. BERGER \& T. LUCKMANN, supra note 76, at 37 ("Because of its capacity to transcend the 'here and now,' language bridges different zones within the reality of everyday life and integrates them into a meaningful whole.").

147. See, e.g., F. NiETzSCHE, On Truth and Lying in an Extra-Moral Sense, in ON RHETORIC AND LANGUAGE 246, 249 (1989):

Every word becomes a concept as soon as it is supposed to serve not merely as a reminder of the unique, absolutely individualized original experience, to which it owes its origin, but at the same time to fit countless, more or less similar cases, which, strictly speaking, are never identical, and hence absolutely dissimilar. Every concept originates by the equation of the dissimilar.

See also P. Brooks, REAdING FOR tHe Plot 281 (1984) ("The closure demanded by narrative understanding - the closure without which it can have no coherent plot-is always provisional, asif, a necessary fiction."); J. DERRIDA, supra note 98, at 258-71 (discussing the "metaphorical sedimentation" of concept).

148. Cf. P. RicoeUR, THE RULE of METAPHOR 286 (1981) ("[W] herever metaphor fades, there the metaphysical concept rises up. We find a text from Nietzsche here to the effect that 'truths are illusions of which one has forgotten that they are illusions; worn-out metaphors which have become 
derives, in varying degrees, from the gap between the concept's claim to some generalized truth and the justifications that it offers to make its claim stick. ${ }^{149}$ From our localized encounters in a particular time and place, we make a leap to generalization. We create categories in order to gather and label-to make coherent-our time-fragmented experiences. ${ }^{150}$ Abstraction is an expedient in the service of our urge for coherence. But it lacks any guarantee of truth. The concept's origin lies in a leap of faith. Its existence is a testament to the human need to preserve order in time. Yet, while human need may account for the concept's motive force, in the field of truth it can prove nothing. The concept's shortfall, therefore, cannot be helped. Moreover, unlike metaphor, there is no sensory perception or image to warrant the concept's existence. 151

But metaphors too lie. ${ }^{152}$ Like concepts, they too make unjustified leaps of

powerless to affect the senses, coins which have their obverse effaced and now are no longer of account as coins but merely as metal.'" (quoting F. NIETZSCHE, On Truth and Falsity in their Ultramoral Sense, in 2 WoRKs 171, 180 (1974) (emphasis in original)).

149. Cf. id. at 302 ("The signifying aim of the concept works free of interpretations, schematizations, and imaginative illustrations only if a horizon of constitution is given in advance, the horizon of speculative logos." (emphasis in original)).

150. Cf. id. at 302-03 ("Interpretation is the work of concepts. It cannot help but be a work of elucidation .... Every interpretation aims at relocating the semantic outline sketched by metaphorical utterance inside an available understanding that can be mastered conceptually.").

Consider, for example, Hart's concept of law as primary and secondary rules in The Concept of Law, Dworkin's concept of law as "integrity" in Law's Empire, or Rawls' concept of law as "fairness" in $A$ Theory of Justice. There are, of course, those thinkers whose underlying conceptual premises (what some refer to as "ideologies" or "prejudices") remain implicit or unwitting. Deconstructive readings have been helpful in bringing to light such "deep structures" of conceptualization. See, e.g., White, supra note 24, at 2020-22 (critiquing Posner for undue reliance upon a scientific or positivistic mode of anaysis as opposed to what White refers to as a "humanistic" view); cf. J. Caputo, The Mystical Element in Heidegger's Thought 264 (1978) (contrasting "calculative" thinking with Heidegger's "meditative" (or poetic) thinking, noting that the latter "makes no use of concepts").

151. The early legal realists used this insight in an exaggerated way, repulsing the abstract concept for the presumably more dependable reality of "fact." See, e.g., Cohen, Transcendental Nonsense and the Functional Approach, 35 CoLUM. L. REV. 809, 823 (1935):

Our legal system is filled with supernatural concepts, that is to say, concepts which cannot be defined in terms of experience, and from which all sorts of empirical decisions are supposed to flow. Against these unverifiable concepts modern jurisprudence presents an ultimatum. Any word that cannot pay up in the currency of fact, upon demand, is to be declared bankrupt, and we are to have no further dealings with it.

Of course, a central lesson of the Critical Legal Studies (CLS) movement has been that the realm of "fact" is no safe haven. In this way, CLS has simply extended the reach of the Legal Realists' deconstruction. That is, it has moved beyond the Realists' questioning of our faith in rationality to questioning our faith in empirically secure "facts."

152. See F. NIETzSCHE, supra note 147, at 248-49:

First, [the creator of language] translates a nerve stimulus into an image! That is the first metaphor. Then, the image must be reshaped into a sound! The second metaphor. And each time there is a complete overleaping of spheres-from one sphere to the center of a 
meaning. When we say "this" is like "that," we create a meaning by virtue of a relation. The meaning is the relation. Even though we readily admit that "this" is not "that," we allow "this" to stand for "that." This standing for opens up our perception, and gives meaning to experience in time, but it also serves to disguise or mask. ${ }^{153}$ The image (or signifier) cannot achieve identity with the object (that which is signified). The conceit of metaphor is that we allow ourselves to forget the difference between "this" and "that" in order to gain the benefit of their relational meaning. If the metaphor's meaning lies in the creative relation between "this" and "that,"the metaphor's fiction lies in our forgetting of their difference. ${ }^{154}$

Based on what has been said so far, we may conclude that uncertainty cannot be overcome. ${ }^{155}$ Our creation of meaning remains an activity that will always lie within the shadow of possible error. This is the challenge and the humbling reality of our existential predicament. Yet, by idealizing narrative as a "crystal" of "pure meaning" and depicting the romanticization of resistance that such a narrative inspires, Cover seems utterly indifferent to this predicament. He seems to have forgotten that every act of meaning creation is enmeshed within a complex network of external (historical, cultural, and contingent) as well as internal (ethical, characterological, and pathological) factors. Put differently, he seems to have forgotten that the stories we read or make up involve plots and subplots of which we may be only partly aware, and over which, in any event, we can exercise only limited control. ${ }^{156}$

totally different, new one. Imagine a person who is completely deaf and never has had a sensation of sound and music. How this person marvels at the Chladnean sound-figures in the sand, identifying their cause as the trembling of the strings, then swearing that now he must know what people call "sound." That is the situation of all of us with language. ... [M] etaphors of things ... do not correspond at all to the original entities.

Cf. S. Langer, Philosophy IN a New Key 21 (1980) ("And the triumph of empiricism in science is jeopardized by the surprising truth that our sense-data are primarily symbols." (emphasis in original)).

153. Sherwin, supra note 5, at 583; cf. P. RICOEUR, supra note 148, at 17 ("[O]ne resorts to metaphor to fill a semantic void ....").

154. See J. DERRIDA, supra note 98 , at 211 ("The primitive meaning . . . becomes a metaphor when philosophical discourse puts it into circulation. Simultaneously the first meaning and the first displacement are then forgotten. The metaphor is no longer noticed, and is taken for the proper meaning. A double effacement.").

155. See; e.g., C. Perelman, The Realm of Rhetoric 6 (1982) (contrasting scientific knowledge premised on "self-evident" intuitions with rhetorical argumentation premised on the unavailability of uncontested first principles); Burt, Constitutional Law and the Teaching of the Parables, 93 YALE L.J. 455, 487-89 (1984) (given the absence of immutable truths, the best we can hope for is not an "end in principle," but merely a "mutually agreed end").

156. See, e.g., P. BRooks, supra note 148, at 90-112 (exploring, through Freud's Beyond the Pleasure Principle, the complexity and compulsion of plot); R. GIRARD, DECEIT, DESIRE, AND THE NOVEL 16 (1988) (describing how the truth of desire, as it is revealed in the great novels of Cervantes, Flaubert, and Stendahl, remains hidden even at the heart of its revelation); Sherwin, supra note 148, at 581-92 (deconstructively revealing plot within J.B. White's Heracles' Bow); and the works of Michel Foucault generally. 
By embracing as a basis for lawmaking the possibility of totalizing in time a particular sectarian truth, Cover openly risks falling victim to the conceit of unconstrained imagination. ${ }^{157}$ It is a mistake that sets him, and those who would follow his lead, on an alarmingly violent path.

The staggering fecundity of our fictions is a testament to our creative nature and a challenge to our ethical imagination. Our meanings may be glorious artifices, but they are artifices nevertheless. ${ }^{158}$ And yet, we remain responsible for these creations; indeed, it is through them that self, other, and social institutions take on an embodied existence in the world. By empowering illiberal belief as a source of law, we give life to a community in which a single, totalized discourse of power closes its ears to other voices. In short, we create a world in which the disbelieving other has no place, no self, and no means of communicating with those in power. Indeed, as one of Cover's final essays starkly and alarmingly reveals, the community that is founded on unconstrained illiberal belief, lacking the means for cross-dialogic and intersubjective communication, constitutes a reality of violent confrontation. ${ }^{159}$ And it is precisely this reality against which liberals have rebelled. ${ }^{160}$

In the public realms of law and politics, non-sectarian argumentation serves as a vital safeguard against the totalized and exclusive discourse of illiberal belief. ${ }^{161}$ By insisting upon the need to provide reasons (or figures, or images, or stories, or abstract concepts, or principles), which is to say, by insisting upon the need to persuade, ${ }^{162}$ argumentative discourse valorizes the

157. See supra text accompanying note 1.

158. $C f$. G. STEINER, AFTER BABEL 233 (1975) (attributing the diversity of languages in part to the "psychic need for particularity"; "the Babel myth is once again a case of symbolic inversion: mankind was not destroyed but on the contrary kept vital and creative by being scattered among tongues"); id. at 229 ("At every level, from brute camouflage to poetic vision, the linguistic capacity to conceal, misinform, leave ambiguous, hypothesize, invent is indispensable to the equilibrium of human consciousness and to the development of man in society.").

159. See Cover, Bonds, supra note 34, at 832-33.

160. See A. CAMUS, supra note 1, at 244-306 (rebellion must be grounded in moderation); Rawls, supra note 28 , passim (developing "political liberalism" as a just alternative to coercive imposition of a single comprehensive doctrine in dealing with the fact of our pluralism).

161. Cf. Fuller, Reason and Fiat in Case Law, 59 HARV. L. Rev. 376, 388 (1946) ("Governmental power supplies the defects of reason, but is in turn powerless unless supported by some rational principle.").

162. As rhetoricians have traditionally taught, the propriety and efficacy of a speaker's choice of discourse turns in part upon context, which is to say, upon the audience being addressed. See, e.g., Aristotle's Rhetoric and Cicero's Topics (1954). This lesson has been carried into the legal culture. See C. Perelman, supra note 13, at 13 ("The only general advice that a theory of argumentation can give is to ask speakers to adapt themselves to their audiences."); J. WHITE, supra note 22, at 28 (viewing law as "rhetoric"; not "as an ignoble art of persuasion ... but as the central art by which culture and community are established, maintained, and transformed"); Sherwin, supra note 5, at 543-44 (noting and supporting the current emergence of rhetoric in law).

With the resurgence of rhetoric, rationalist conceptions of reasoned argumentation may be supplemented by a far richer array of argumentative discourses, each with its own standards of propriety and efficacy. As a result, scientific talk about "neutral principles" or "premises" may come to be 


\section{dignity and worth of the other. ${ }^{163}$ To be successful, persuasion requires sen-}

seen as unduly constrictive (if not outright deceptive) with regard to the exclusive claims it would make upon our belief. It may also become clear that this kind of persuasion simply cannot do justice to the full range of human experience. Neither logic nor economic calculation, for example, can touch the emotions or move the imagination in the same way that a striking image or metaphor might. Persuasive speech must at times address a fuller range of human life and experience than calculation or inferences or deductions allow. See Brennan, Reason, Passion and "The Progress of the Law," 10 CARDozo L. REV. 3, 3 (1988) ("It is my thesis that this interplay of forces, this internal dialogue of reason and passion, does not taint the judicial process, but is in fact central to its vitality."); White, supra note 26, at 2016-18 (contrasting the traditional dominance and "structurally coercive" aspect of scientific rationality with the "affective," "invitational," and "constitutive" aspects of "humanistic" discourse).

Of course, we cannot let the richness of rhetoric blind us to the need for discursive and institutional constraint. See Sherwin, supra note 14, at 824-49 (on institutional and discursive competencies); $c f$. Luhmann, The Self-production of Law and its Limits, in DILEMmas OF LAW IN THE WeLfare STATE 111, 120 (G. Tuebner ed. 1986) (noting that "no functional subsystem is able to solve the core problems of another system" (emphasis in original)). Yet, the rhetorical approach does more than merely broaden our respect for the power and range of human imagination; it also broadens the range of critical analysis. For example, the mode of argumentation that a speaker chooses tells us much about her vision of the social world, the other she is addressing, and the social, political, or institutional concerns that might be at issue.

Consider, for example, the contrasting attitudes toward metaphor in Oregon v. Elstad, 470 U.S. 298, 303-04 (1985) (describing the "cat out of the bag" rule as "just" a metaphor), and Griswold v. Connecticut, 381 U.S. 479, 484 (1965) (using the metaphor of "penumbras" as a basis for expanding specific guarantees in the Bill of Rights), and Lemon v. Kurtzman, 403 U.S. 602, 614 (1971) (Brennan, J.) (Court "must recognize that the line of separation [between church and state], far from being a 'wall,' is a blurred, indistinct, and variable barrier depending on all the circumstances of a particular relationship"), and Everson v. Board of Educ., 330 U.S. 1, 16, 8 (1947) (Black, J.) (the creation of a "wall of separation between church and State" is a response to the "turmoil, civil strife, and persecutions" that gave rise to the establishment clause in the first place (citation omitted)). Taking up the latter example, the Court's more recent reliance upon governmental neutrality (Lemon's "secular purpose" test) reflects a picture of political and social reality that is in sharp contrast to the one Justice Black had in mind. May we not conclude that Justice Black's harsher imagery reflects (and indeed generates) a more critical response to the political or social reality of the time than Justice Brennan's more neutral or tolerant depiction of social or political reality would allow? Images give fuller life to the values that inform and guide judgment. Thus, they warrant our closest scrutiny.

163. See Johnstone, Some Reflections on Argumentation, in PhILOSOPHY, RHETORIC AND ARGUMENTATION 30, 35-36 (H. Johnstone and M. Natanson ed. 1965).

Non-argumentative forms of control do not establish the self. Instead they bypass it. They proceed on the assumption that the self is not present to interfere with their effective administration. The command, the subliminal suggestion, the hypnotic pass, avoid the risk of dealing with the self. ... When a [person] is given to using non-argumentative means of control we have no compunctions about using non-argumentative means against him, on the grounds that he has not shown himself to be a person.

It is on the basis of such persuasive arguments in favor of persuasion that $I$ would resist analogizing legal decisionmaking either to prophetic or parabolic discourse, because both of these in my view function by conversion rather than persuasion. See J. CAPUTO, supra note 150, at 270 ("Now I ask you to be so poor that you may understand this discourse. For I say to you by the eternal truth: if you do not make yourselves like to this truth of which we are now speaking, then you will not be able to understand me." (quoting M. EcKHART, MEISTER ECKHART 227 (R. Blakney trans. 1941)); cf. M. PERRY, supra note 134, at 98-99 (describing the judicial task as one of "prophecy"); Burt, 
sitivity to one's audience. This ability describes the capacity for empathy. ${ }^{164}$ Without this ability, the speaker's response may not only fail to persuade, but may actually disenchant. For if the terms the speaker chooses fail to reflect the other's understanding of her situation, she may experience the speaker's discourse as a denial of her subjective reality. By extension, it is also empathy that allows the speaker to ascertain what the other considers reasonable to accept. ${ }^{165}$ To be capable of empathy, however, requires self-constraint. Absent such constraint one may speak, but one cannot listen; one may proclaim or even command, but one cannot persuasively reason. It is precisely this constraint, therefore, that makes dialogue possible.

Empathy alone, however, is not enough. Commitment in principle to the ideal of mutually respectful discourse cannot wash away the limitations built into the different forms of discourse that are at play within our society. For example, even an extraordinary empathic ability may not equip the lay citizen to appreciate fully the meaning and consequences of a judicial decision interpreting the federal constitution. ${ }^{166}$ By the same token, judicial or legis-

supra note 155, at $467-78$ (drawing "parallels between the secular authority of the Constitution in the polity and the divine authority of the Gospels in religious belief").

164. See C. GeerTZ, LoCal KNowledge 59 (1983) (describing the need to see the other's experiences within the framework of the other's idea of what selfhood is); Brennan, supra note 160, at 22 (using "empathy" to signify the sensitivity courts should employ to counterbalance sheer rationality); Henderson, Legality and Empathy, 85 MrCH. L. REV. 1574, 1576 (1987) ("empathy is a form of understanding" that enables decisionmakers to appreciate the human meaning in a legal problem).

The Supreme Court's recent decision in Allegheny County v. American Civil Liberties Union, 109 S. Ct. 3086 (1989), provides an excellent illustration of how an illusory sense of solicitude toward the other can take the place of genuine empathy. In Allegheny, the Court found that a creche display inside a county courthouse communicated the government's endorsement of a patently Christian message. Id. at 3103-05. But in assessing the "message" of the object, only Justices Blackmun, Stevens, and O'Connor went beyond considering not only the context of the object but also the context of the viewer to whom the message was being sent. Id. at 3101-03.

In rhetorical terms, one may conclude that the Court in Allegheny got the right message in focus-religious symbols may have the power to alienate-but the right audience-the "insiders"? the "outsiders"? the "reasonable observer"? the disbelieving other? the "residents of Pittsburgh"? remains unclear. And therein lies Allegheny's disempathic effect.

165. See Minow \& Spelman, Passion for Justice, 10 Cardozo L. Rev. 37, 50 (1988) (one of the criteria for evaluating judges (and consequently a norm for judges themselves) should be that the judge "try to take the perspective of all parties before the court prior to reaching a decision"); Sherwin, supra note 5, at 592-610 (given the diversity of discourses, the task for the prudent arbiter is "to create a shared world by speaking the other's tongue" (footnote omitted)).

166. See, e.g., Bruton v. United States, 391 U.S. 123, 135-37 (1968) (concluding that a lay jury could not be expected to follow a trial judge's instructions to consider one defendant's confession only as to that defendant's guilt or innocence and not as to a codefendant whom the confession directly inculpates); Jackson v. Denno, 378 U.S. 368, 388-91 (1964) (concluding that a lay jury could not ascertain the legal admissibility at trial of a criminal defendant's confession and then abide by a trial judge's instructions to disregard the confession with regard to the defendant's factual guilt or innocence); see also R. DwORKIN, TAKING Rights SERIOUSLY 129 (1977) ("It does not follow from the fact that the man in the street disapproves of abortion, or supports legislation 
lative discourse may be so insulated from the citizen's ordinary common sense that statutes and judicial rulings may cease to command public compliance.

Proceeding, then, from the discourse ideal as a common point of departure, having thus established a shared normative basis for the legitimacy of our political and legal institutions of power, it is necessary next to ascertain guidelines for conventional institutional practices. Publicly recognized rules for assessing the norms and facts that are to govern contextualized interpretations and applications of the discourse ideal must be specified. Otherwise, as Rawls has aptly noted, there is no agreed way for determining whether the shared ideal has been fulfilled or for settling what that ideal requires of particular institutions in particular contexts. ${ }^{167}$ With broad public acceptance of guidelines for localized discursive practices, we may move toward resolving the highly controversial issue of who gets to speak how about what-and with what official (i.e., state-backed) effect.

Faced with a plurality of possible normative constructions of social reality, the question arises: How do we regulate conflicting and perhaps incommensurable ways of thinking and speaking about a given controversy? Which discourse do we empower to have "the inal say"? I believe it is precisely this concern that the constitutional division of delegated governmental powers effectively addresses. To support this view, however, the institutionalization of discursive diversity within our constitutional democracy will need to be rhetorically construed.

We begin with "the fact of pluralism."168 In rhetorical terms, this means we begin by explicitly recognizing (and self-reflectively assessing) the discrete discourses of power that are operating within our society. We will also note that different discourses (or discursive communities) come into play depending on the occasion, with each speaker calling upon her own community's characteristic modes of thinking and sources of persuasion. For example, in public debates the lay citizen generally can be expected to rely upon the local knowledge or customary expectations that are made available to her through the discourse of ordinary common sense. ${ }^{169}$ Common sense discourse is generally not privy to the inherited legal texts and the procedural norms of decisionmaking familiar to lawyers and judges, nor to the empirical studies and

making it criminal, that he has considered whether the concept of dignity presupposed by the Constitution, consistently applied, supports his political position.").

167. See Rawls, The Idea of an Overlapping Consensus, 7 OxFord J.L. STUD. 1, 8 (1987).

168. Id. at $1,4-5$.

169. See id. at 8 (fixing on the discourse of common sense as the only discourse that can generate a true "free public reason" in the midst of our pluralism). For a fuller analysis of the hidden diversity of common sense and the multiplicity of discourses that operate within our pluralistic society, see Sherwin, supra note 14, at 737-49 (identifying three discrete criminal procedure dialects: ordinary common sense, prudent interpretation, and scientific policymaking). 
relatively fixed policy goals that inform legislative debate. Yet, within our constitutional democracy, it is the lay citizen who holds supreme power. "We the People" can decide to change our institutional framework or revise fundamental norms through the process of constitutional amendment. ${ }^{170}$

Except for those rare periods of heightened political awareness when the citizenry may be moved to do constitutional politics on their own, ${ }^{171}$ however, citizens generally depend upon legislative representatives to express the public's will. The legislature ordinarily achieves this through the process of policymaking and statutory enactment. Those who seek to maximize the effectiveness of this legislative activity may aspire to a higher order of generality than that which the variable, and often internally inconsistent, local knowledge of ordinary common sense allows. ${ }^{172}$ Comprehensive policy goals offer a means toward such systemization. ${ }^{173}$ Thus, it may not prove surprising to find the comprehensive discourse of utilitarian or cost/benefit analysis competing in legislative debate with alternative (non-instrumental) discourses, such as ordinary common sense or a more comprehensive claim of "Right."174 At the same time, however, we may also note that comprehensive policy goals which are fit for legislative debate may not be fit for the courts. Neither comprehensive policymaking - nor, for that matter, ordinary common sense-will do justice to the inherited sources of authority (constitutions, statutes, or judicial precedents) and procedural norms of decisionmaking (such as the doctrine of stare decisis) with which lawyers and judges must persuasively contend in the context of specific, concrete controversies. Indeed, only with the greatest of difficulty can comprehensive policy goals

170. Notably, Rawls claims that the discourse of common sense is the only discourse by which we can establish agreement on a unifying conception of justice. See Rawls, supra note 167, at 8. To the extent that "We the People" are the supreme power in our constitutional democracy, this claim may be correct. However, as an account of conventional power talk, ordinary common sense fails to do justice to the complex reality of our discursive situation in society.

171. See Ackerman, The Storrs Lectures: Discovering the Constitution, 93 YALE L.J. 1013, 1022 (constitutional politics should dominate the nation's political life only during "rare periods of heightened political consciousness").

172. See C. GeERTZ, supra note 164, at 215-26 (exploring tension between an ideal of law as identifiable unified principle and a reality of law as local knowledge; observing cultures' efforts "to comprehend their legal world in terms too integral ... to represent it realistically" or to "abandon[ ] much hope of comprehending it, save opportunistically, at all").

173. See B. ACKerman, Privitte Property and the Constitution 20-87 (1977) (describing the discourse of "scientific policymaking" as being organized around "a single comprehensive view" that may be constituted either by Kantian (rational) principles or utilitarian (empirical) calculations, and arguing in favor of this type of specialized, comprehensive power talk over the conventional observations (or customary expectations) of the lay person).

174. See Fletcher, Human Dignity as a Constitutional Value, 22 U.W. ONTARIo L. REv. 171, 175 (1984) (referring to the Kantian "structure of Right ... that guarantees to every individual the freedom to act on his private choices"); see also J. RAwLS, A THEORY OF JUSTICE 4 (1971) ("[T]n a just society ... the rights secured by justice are not subject to political bargaining or to the calculis of social interests."). 
admit the contextualized needs, desires, or claims of right to which particular parties give voice. ${ }^{175}$

In short, each of these separate discourses-the lay citizen's ordinary common sense, the legislator's comprehensive policymaking, and the jurist's contextualized interpretation of inherited texts-utilizes a characteristic form of persuasion. Each discourse appeals to the evidence and norms available to its own particular discursive community. Moreover, each discourse uses "reasons" (i.e., stories, images, calculations, or principles) in a way that the discourse in question and the institutional setting allow. ${ }^{176}$

On this analysis, then, the rules for assessing and applying discrete discourses of power emerge not only from the discourse's institutional context-whether general public debate, legislative policymaking, or judicial decisionmaking - but also from the particular discourse itself. For upon reflection we find that each discourse has its own characteristic virtues and drawbacks. Put simply, once called into play, there are some things a particular discourse can persuasively assert and other things that it cannot. For example, while the local knowledge of ordinary common sense may effectively articulate particular (and often conflicting) customary norms, it lacks the stabilizing consistency needed for effective national or even local policymaking. Perhaps even more importantly, common sense also tends to lack the self-constraint necessary to check the tyranny of majoritarian belief. ${ }^{177}$

175. See J. WHITE, supra note 22, at 1-27, 192-214 (describing the ethical consequences of comprehensive "systems design" talk and of utilitarian discourse generally upon the constitution of self, others, and social institutions).

For an argument that explicitly questions the use of comprehensive policymaking as a legitimate source of judicial authority, see Sherwin, supra note 14, at 830-33; see also Kamisar, Does (Did) (Should) the Exclusionary Rule Rest on a 'Principled Basis' Rather than an 'Empirical Proposition'?, 16 Creighton L. REv. 565, 656-67 (1983) ("[w] hen the [Supreme] Court acknowledges ... that it has no constitutional business excluding evidence obtained in violation of the protection against unreasonable search and seizure," it does not have "any business at all doing so" and should leave the balancing of conflicting interests to the legislature (emphasis in original)); Weinrib, Understanding Tort Law, 23 VAL. U.L. Rev. 485, 488-89 (1989) (discussing tort law not as the means of furthering a set of social goals, but as "a coherent and integrated whole").

176. What is "self-evident" to some (but not other) citizens in public debate may be nullified in principle by a judicial opinion. And what is deemed desirable in legislative debate on the basis of comprehensive views may strike some lay folk as plain wrong, and some jurists as constitutionally impermissible. Finally, as already noted, if enough folks feel that constitutional interpretation by the courts has gone too far in the wrong direction, they may organize to amend the Constitution itself. Notably, each group will "reason" with the other in terms that are natural to the discourse being utilized: either from the "self-evident" (albeit conflicting) premises of ordinary common sense; from the "self-evident" (albeit totalizing) premises of a subjectively preferred comprehensive view; or from interpretive principles that are derived from inherited legal texts. Each discourse, moreover, will come into play in accordance with an institutional framework established by our constitutional scheme of divided and delegated governmental powers.

177. Consider, for example, the public outrage that greets a decision like Texas v. Johnson, 109 S. Ct. 2533 (1989), for "sanctioning" flag burning in the name of the interpretive principle of freedom of political expression. 
the basis of fixed principles or utilities, the rigidity of its premises and its insensitivity to specific localized contexts render it susceptible to the tyranny of ideological exclusivity. Indeed, it may well be that the particular is a natural casualty of comprehensive viewpoints. ${ }^{178}$ While not wholly immune from this same drawback, the courts' sensitivity to localized contexts and claims may temper the harsh effect of rigid comprehensive policy goals, just as the jurist's reliance upon inherited texts and procedural norms of decisionmaking may provide a hedge against totalizing ideological (or other comprehensive) beliefs. Nevertheless, this judicial virtue-like the virtues of common sense and comprehensive policymaking - cannot escape a characteristic drawback. For it is precisely the courts' willingness to "accommodate" principle to context that risks eviscerating principle altogether. ${ }^{179}$ Counseled by prudence, or perhaps out of fear that the necessary public compliance will not otherwise be obtained, courts frequently shy away from the counterintuitive meaning or countermajoritarian effect of inherited principles. ${ }^{180}$ In this way, they risk turning judicial law into an amalgam of inconsistent and unpredictable norms resembling the local knowledge of ordinary common sense.

A constitutional system that is committed to the normative ideal of intersubjective communication between free and equal persons must effectively

178. Consider, as an illustration of the natural tension between the comprehensive and the particular, the judicial discourse in Sulie v. Duckworth, 689 F.2d 128, 130-31 (7th Cir. 1982) (defendant's post-arrest and post-Miranda warning request for counsel allowed to be used against him at trial to impeach his insanity defense), cert. denied, 460 U.S. 1043 (1983). According to Judge Posner, writing for the court, the analysis turned on "how much the exercise of the right to remain silent would be deterred if a suspect knew that a request for a lawyer could be used as evidence of his sanity." Id. at 130. Judge Posner answered: "Not much, in our opinion." Id.

In his dissenting opinion, Judge Cudahy took issue with the majority not only for its questionable use of untested empirical assumptions, but also, in the court's rush to implement its "balancing analysis," for apparently losing sight of the particular defendant altogether:

[I]n the criminal context, the relevant question is whether the particular defendant has been harmed by the State's use of the fact that he engaged in constitutionally protected conduct, not whether, for the particular defendant or for persons generally, the State's reference to such activity has or will burden the exercise of a constitutional right.

Id. at 132 (Cudahy, J., dissenting) (emphasis added to word particular) (quoting United States ex rel Macon v. Yeager, 476 F.2d 613, 616 (3d Cir.), cert. denied, 414 U.S. 855 (1973)).

179. See Sherwin, supra note 14, at 784-90 (describing the potential for evisceration present in the Miranda majority's strategy of controversy reduction; in attempting to retain an appearance of judicial flexibility, the majority distanced its rule from the constitutional source, sowing the seeds of the rule's demise).

180. See Kronman, Alexander Bickel's Philosophy of Prudence, 94 YALE L.J. 1567, 1573-90 (1985) (recounting Bickel's advocacy of a prudential process of adjudication "through which the Court's idealistic search for enduring values is accommodated to the majoritarian elements in the general constitutional scheme"); Sadurski, "It All Comes Out in the End": Judicial Rhetorics and the Strategy of Reassurance, 7 OXFORD J. LEGAL STUD. 258, 272 (1987) (courts moderate possible conflicts with majoritarian values when making predictably unpopular decisions). 
deal with the respective drawbacks of discrete discourses. I contend that our system of divided powers does this by allowing the virtues of one discrete discourse to check and balance its own and other discourses' characteristic drawbacks. In this way, common sense may appropriately triumph in public debate, but not in judicial decisionmaking. Similarly, while a comprehensive view may appropriately triumph in legislative policymaking, it may not properly do so in the separate institutional context of judicial decisionmaking, where text-based interpretive principles order and contextualize specific outcomes. ${ }^{181}$ Disturbances within the process of discursive checks and balances ${ }^{182}$ tend to allow one discourse to dominate (and exclude) other languages of power. As a result, the dominant discourse's characteristic drawbacks remain unconstrained. This "illiberal" condition invites the tyranny into which that particular unchecked and unbalanced discourse typically decays. ${ }^{183}$

We may conclude from this rhetorical analysis, as Rawls has recently concluded from the standpoint of political philosophy, ${ }^{184}$ that no single comprehensive moral, philosophical, theological, or ideological viewpoint can do

181. See Sherwin, supra note 14 , at $828-44$ (describing checks and balances among the discrete virtues and defects of ordinary common sense, scientific policymaking and prudent interpretation within the criminal justice system).

182. "Disturbances" in this context include: ideological distortions (e.g., using a discourse to make inappropriate claims, like the judicial interpretive claim that the Constitution is an exclusively deontological or utilitarian text); tactical distortions (e.g., masking the meaning of inherited texts or omitting relevant judicial precedents); and political distortions (e.g., shifting the balance of power from one institutional agency to another for the purpose of self-aggrandizement).

183. The form of tyranny depends upon which discourse dominates. See Sherwin, supra note 14, at 848-49:

The form of tyranny that a particular, dominant dialect will take corresponds to its discrete defects. For example, because ordinary common sense lacks reflection, its "self-evident" truths characterize reality in inconsistent and unpredictable ways. This is the majoritarian tyranny: muddled, unruly, readily unmindful of counter-intuitive (textual or institutional) principles or comprehensive social policies. Because prudent interpretation takes specific, concrete conflicts as its point of departure, its contextualized interpretations risk, on the one hand, unpredictability and the appearance of discontinuous and unregulable standards. On the other hand, its awareness of this danger breeds strategic devices that threaten to unravel its own principled framework. This is the interpretive countermajoritarian tyranny: constantly caught in a tense and uncertain compromise between principle and compliance. Because scientific policymaking takes its point of departure from particular "self-evident" axioms or principles, like ordinary common sense, it totalizes truth. However, because, unlike common sense, it is reflective, its totalization is systematic and invariable. This is the countermajoritarian tyranny of a preferred (comprehensive) policy: ever willing to conform reality, and in some instances even to sacrifice the particular needs and desires of parties in a concrete controversy, to the rigid demands of "self-evidently" preferable comprehensive and self-consistent principles or ends.

184. See Rawis, supra note 167, at 4-5 (given the "fact of pluralism" in modern democratic cultures, "no general and comprehensive view can provide a publicly acceptable basis for a political conception of justice"). 
hensive moral, philosophical, theological, or ideological viewpoint can do justice to the historical and institutional realities of our constitutional democracy. This is particularly so with regard to what Rawls has called "the fact of pluralism."185 Unlike the comprehensive views noted above, however, our commitment to a shared normative ideal like the discourse ideal that I have been describing can provide a coherent basis for social unity within which the normative controversies of conventional institutional practices may be reasonably contained. ${ }^{186}$

By engaging in the constitutionally institutionalized processes of argumentative discourse described above, we not only valorize the dignity and worth of the other in diverse discursive contexts, but we also valorize the overarching ideal of the dialogic process itself. ${ }^{187}$ Thus, in seeking an alternative to the nomos of totalized truth that Cover dared to imagine, we arrive at the liberal discourse ideal. It is the path we have been on from the beginning.

In contrast to Cover's post-messianic view, and in keeping with the exemplary professionalism of Rabbi Karo, I submit that it is only by keeping acts of faith and legal argumentation apart, ${ }^{188}$ and by reflectively tempering belief with suspicion, ${ }^{189}$ that we may avoid Cover's romanticization of violent resistance and its totalitarian consequences. When the force of faith that sustains the word of the prophet unites with the force of law, the unconverted other stands in constant danger of being silenced. Yet, neither can Cover's pre-messianic perspective serve as a proper basis for lawmaking. For from this anarchic perspective, there is simply no ground for attributing more or less authority to any individual community of meaning. And without any means of establishing mutually acceptable criteria for legitimacy amid the conflicting claims of discrete and insular discursive communities,

185. One may add that it is precisely the incommensurability of the discrete discourses currently operating within our society-which is to say, it is precisely the fact of their radical heterogeneity (but not incompatibility)-that makes it important to recognize in principle the discontinuity, and concomitant need for mutual checks and balances, in order to assure the autonomy of each discourse and the community which that discourse helps constitute. This points to how autonomy and community are complementary (or mutually dependent) aspects of conventional discursive practices within the liberal constitutional framework.

186. I use the word "reasonably" here in its full rhetorical richness, which is to say, with an awareness of the diverse modes of reasoning that discrete discursive practices embody.

187. See B. ACKERMAN, supra note 6, at 308 ("For a liberal statesman, the most basic right of any citizen is the right to have his question of legitimacy answered in a liberal conversation." (emphasis in original)).

188. See J. LockE, supra note 6 , at 172 ("the care of souls is not committed to the civil magistrate").

189. See Boyer, Agents, Lovers, and Institutions: John Le Carré as Legal Critic, 65 NOTRE DAME L. REv. 78, 106 (1990) (criticism "keep[s] the status quo from ossifying"); Sherwin, supra note 5, at 558-63 (proposing model of critical rhetorical practice designed to avoid both the destructive incoherence of pure suspicion and the mistaken faith of pure rhetoric). 
there can be no legal order for them to share. 190

In place of Cover's anarchic account (of unconstrained normative worlds) and his post-messianic account (legalizing the telos by identifying law with redemption), I submit that it is the liberal principle of discursive constraint (authorized by the shared constitutional ideal of mutually respectful discourse) that offers the most reliable basis upon which we may assess the creation, conservation, and denial of legal meanings. Put differently, it is on the strength of our interpretive commitment to the liberal discourse ideal that we may appropriately constrain legal violence. ${ }^{191}$ In this way, we may also enhance what Cover once referred to as the judicial decisionmaker's peaceful, regulative function. ${ }^{192}$

Ironically, with our recognition of the danger of utilizing illiberal belief as a basis for legal interpretive commitment, we encounter not only a clear limiting case for violent resistance, but also the point of origin for the liberal tradition itself. ${ }^{193}$ To the extent that "totalitarian" state violence renders incoherent the unconverted other's sense of self and community, ${ }^{194}$ she obtains the warrant she needs to resist official authority. ${ }^{195}$ To avoid the need for this kind of violence, the primary hermeneutic task of any official decisionmaker is persuasively to articulate the basis upon which the other may reasonably accept a preferred legal interpretation. Put differently, the legitimation of power depends, in significant part, upon the shared normative ideal and diverse institutional practices of argumentative discourse. ${ }^{196}$ To

190. Cf. Kahn, Community in Constitutional Law, 99 YALE L.J. 1, 62 (1989) ("For Cover, the discursive community, not the private individual, is the basic unit of social reality. This community is not a part of, but rather an alternative to, the state ... . A choice must be made, therefore, between the anarchy of meaning and the politics of violence." (footnote omitted)).

191. Cf. Ingram, Hermeneutics and Truth, in Hermeneutics AND PRAXIs 32, 40 (R. Hollinger ed. 1985) (" $[T]$ hough there may not be any discourse which is capable of uniting speakers standing in incommensurable world-horizons, there still remains the meta-hermeneutical pre-condition which binds them together in a common effort to achieve agreement, namely, mutual recognition and openness." (emphasis omitted)).

192. Cover, Nomos, supra note 5, at 53; cf. E. LeviNAS, supra note 15, at 17 (see quoted material at note 15$)$.

193. See Everson v. Board of Educ., 330 U.S. 1, 9-14 (1947) (recounting the religious turmoil that gave rise to the governmental constraint embodied in the establishment clause).

194. This is a phenomenon I have referred to elsewhere as the silencing or exile of discrete rhetorical communities through an illegitimate exercise of judicial power. See Sherwin, supra note 5, at 595; Sherwin, supra note 14, at 848. For an expression of protective concern for communities and the processes integral to their effective political participation, see United States v. Carolene Products Co., 304 U.S. 144, 152 n.4 (1938) (suggesting that legislation might be subjected to more exacting judicial scrutiny if it were found to restrict political processes relating to such protected activities as the right to vote, to disseminate information, to form political organizations, or to assemble peaceably, or if it were found to prejudice "discrete and insular minorities").

195. See Sherwin, supra note 13 , at $396 \& \mathrm{n} .83$ (arguing that as long as citizens are required merely to obey-and not accept-primary rules, obedience may not necessarily extend beyond coercive obligation).

196. See supra notes 161-187 and accompanying text (on the ideal of argumentative discourse 
the extent that such discourse (either imprudently or out of some profound normative antinomy) fails to gain broad public compliance, a legitimation crisis may be at hand.

\section{UNION AMID DIVERSITY: RESTATING OUR HISTORICALLY SHAREd PUBLIC WORLD}

So far, I have endeavored to establish in theoretical terms the worthiness of the discourse ideal. A brief excursion into our country's past may help give a more concrete embodiment to my claims. For this purpose, consider the playing out of Cover's post-messianic vision of legal meaning within the context of the antebellum conflict between the slave-holding South and the abolitionist North-two distinct normative realities vying for dominance. ${ }^{197}$

Cover has told us that law is a bridge connecting present reality to an imagined future. But this understanding immediately leads, as we have seen, to the question: by what criteria do we assess the legitimacy or illegitimacy of the authority on which such imaginative projections rely? Speaking truth to power in this particular historical context encompasses distinctly different meanings. On the one hand, it may mean backing up with violence a commitment to some extralegal narrative. Consider, for example, the South's adherence to an unwritten cultural constitution, 198 or William Lloyd Garrison's repudiation of text-based constitutionalism in the name of his own sectarian-based ("redemptive") constitutionalism. ${ }^{199}$ On the other hand,

and its disparate contextual forms); $c f$. Cornell, supra note 10, at 170 (the legacy of the Enlightenment is that "authority can only rest on intersubjective debate and participation").

197. For one contemporary perception of the distinction, see R. HILDRETH, DeSPOTISM IN AMERICA 8 (1854 \& photo. reprint 1968):

The Northern States of the Union are unquestionable Democracies, and every day they are verging nearer and nearer towards the simple idea and theoretic perfection of that form of government. The Southern States of the Union, though certain democratic principles are to be found in their constitutions and their laws, are in no modern sense of the word entitled to the appellation of Democracies: They are Aristocracies; and aristocracies of the sternest and most odious kind.

198. See R. Ferguson, LAw ANd Letters in American Culture 293-94 (1984):

The code of honor and slavery both impinged upon formal legal prerogatives. The leaders of the Old South settled matters of slander, libel, assault, battery, and other differences of opinion on the field of honor, bypassing courtroom remedies and overtly breaking state laws that prohibited dueling. At the same time, slavery barred a third of the South's population from the legal rights of citizenship, and it placed the plantation owner above the law by allowing him to wield absolute power over those people who were his personal property. These tendencies were part of the "unwritten constitution of the Old South" ....

See also W. Braden, The ORal Tradition in the South 26-40 (1983) (discussing the "folkways" and other local ties that made Southerners "a genuine folk long before the Civil War" (quoting F. OWRSLey, Plain Folk IN The Old South 90 (1949))).

199. For an example of his rhetoric, see Speech by William Lloyd Garrison, "No Compromise with Slavery" (Feb. 14, 1854), reprinted in AMERICAN FORUM: SPEECHES ON HISTORICAL IsSUES, 
"speaking truth" may proceed on the basis of accepted legal texts, such as that foundational narrative which holds itself out as the supreme law of the land, the Constitution. ${ }^{200}$

To be sure, conflicting interpretive commitments stemming from the same constitutional text may ultimately require force before one reading is accepted as law. ${ }^{201}$ In this respect, we can accept Cover's understanding of the violence of law and the inevitability under certain (extreme) social conditions of violent resistance to state dominance. No community can be expected to defer to power when the coherence of its world is threatened with extinction. ${ }^{202}$ However, to the extent that Cover's view of law as the projection of possible future worlds legitimates reliance upon sectarian (or other "extralegal") authorities as well as upon sectarian interpretations of constitutional (or other "legal") authorities as sources of lawmaking co-equal to nonsectarian constitutional interpretation, it is a view that deserves to be challenged.

By ratifying a foundational or constituting text as supreme authority for the nonsectarian norms of order, union, justice, social tranquility, defense, welfare, and liberty, ${ }^{203}$ the states united in a commonly shared public world.

1788-1900, at 169, 173 (E. Wrage \& B. Baskerville ed. 1960) ("The Abolitionism which I advocate is as absolute as the law of God, and as unyielding as His throne.").

200. Consider, in this context, Spooner's antebellum repudiation of Garrisonian anti-constitutionalism on the claimed authority of the Constitution as a document embodying "natural law." L. Spooner, THe UnconstrtutionaltTy of Slavery passim (1860). But see W. Phillips, ReVIEW OF LYSANDER SPOONER'S ESSAY ON THE UNCONSTITUTIONALITY OF SLAVERY passim (1987) (repudiating Spooner's analysis as "extra-legal" constitutionalism).

201. To avoid this, our constitutional union encompasses reform by institutionalizing the practice of constitutional amendment. The constitutional disintegration that secession probably would have entailed would have meant the disintegration of a normative context for reconstitutionalization. That is to say, by substituting violence for an existing normative framework for change, secession squarely held out the possibility that peaceful normative order among the once united factions would not be restored. For an earlier portrayal of the anarchy promised by secession, see Speech by Daniel Webster, "The Constitution Not A Compact Between Sovereign States" 15-17 (Jan. 1833), arguing that if the Union is but a league of states and any state can secede from the Union at her own pleasure, then:

any State may resist a law which she herself may choose to say exceeds the power of Congress .... She may make reprisals; she may cruise against the property of other members of the league; she may authorize captures, and make open war.

... If one State may secede, ten may do so, twenty may do so .... Sir, as these secessions go on, one after another, what is to constitute the United States?

202. Although, as Socrates' example teaches, respect for the processes and institutions of law may transcend rebellion against its particular temporal (and "erroneous") interpretations. See PLATO, supra note 15, at 39.

203. See U.S. CONST. preamble; cf. J. LOCKE, supra note 6, at 172 ("Civil interests I call life, liberty, health, and indolency of body; and the possession of outward things, such as money, lands, houses, furniture, and the like."); McConnell, The Origins and Historical Understanding of Free Exercise of Religion, 103 HARV. L. REV. 1410, 1465 (1990) ("[G]overnment is instituted by the people in order to secure their rights to life, liberty, and the pursuit of happiness. Governmental powers are limited to those needed to secure these legitimate ends. In contrast to both ancient and 
A sectarian transformation of that union could mean one of two things. First, it might mean that some members of the public have decided to place their full interpretive commitment behind a text other than the Constitution and are willing and prepared to back that commitment in blood, if need be. This is the reality of total revolution. ${ }^{204}$ It expresses a readiness to risk all. A second type of sectarian transformation could take place in the form of a sectarian reading of the constitution itself. But this "interpretive" move is no more constitutional than revolution. For instead of seeking to discover the constitution, a sectarian reading seeks to impose meaning from a privileged extralegal (e.g., biblical) source of authority. As we have seen, this sectarian approach risks exiling the unconverted other from the ranks of the constitutional community. And it can provide neither a reasoned justification for doing so, nor a meaningful opportunity for the excommunicated other to register her protest. It is as if the other and her world ceased to exist.

On this analysis, the problem with Cover's broad view of lawmaking is that it fails to distinguish between sectarian and nonsectarian interpretive commitments. Indeed, his romanticization of the heroics of resistance 205 appears to rest upon the assumption that interpretive commitment will make law regardless of its textual source or the nature of the interpretive community that enforces it. According to Cover, it is precisely the deed (of violence) that will transform a community's interpretive commitment into a species of "true constitutionalism." ${ }^{206}$ But if this is so, the Civil War loses its special status in our history as a highly unusual occasion of extremely violent confrontation. Indeed, taking Cover's violent vision of lawmaking to heart, the Civil War might well be viewed as a paradigm. It matches precisely the kind of social reality that one would expect to result from a vision in which the basis for union either remains perpetually up for grabs or frozen within the grip of a totalizing sectarian belief system.

The type of lawmaking that Cover imagines, a form of jurisgenesis that romanticizes martyrdom, ${ }^{207}$ contrasts sharply with the liberal practice of argumentative discourse and the liberal principle of discursive constraint that I have described. By losing sight of the separation that the Constitution has

modern non-liberal regimes, government is not charged with promotion of the good life for its citizens.").

204. See Webster, supra note 201, at 17-21 (ignoring the restraints of the constitutional text (specifically, deference demanded to the federal government) in favor of effectuating one's own desires "introduces a new paramount authority into the rule of the State," which is the definition of "revolution").

205. Evidenced, for example, by his almost hagiographic description of the right-to-life protesters. See Cover, Bonds, supra note 34, at 831-33; supra notes 51-52 and accompanying text.

206. Cover, Bonds, supra note 34, at 832.

207. See id. at 833 ("To stop short of suffering or imposing violence is to give law up to those who are willing to so act."); Cover, Violence, supra note 34, at 1605 ("A legal world is built only to the extent that there are commitments that place bodies on the line."). 
created between public nonsectarian norms and private sectarian beliefs, ${ }^{208}$ Cover does violence to the establishment of a supreme public law. A privileged article of faith may meet a private yearning for redemption, but in the public realm of the law, the zeal of faith tends to give rise to precisely the type of passionate, exclusive, and totalizing commitment that makes violence a way of life. One way in which it allows this to occur is by externalizing authority, thereby allowing individuals to forsake direct responsibility for their acts. ${ }^{209}$ All too often, totalizing the word of the absolutized other makes dialogue with the finite other impossible. Dialogue's loss thus becomes violence's gain. But violence has always come easier with absolute authority on one's side.

To counter the anarchic and sectarian extremes to which Cover's broad view of lawmaking leads us, I offer a plea for nonsectarian constraint. ${ }^{210}$ While this view retains many of Cover's important insights regarding the law's violence, it stands against his tendency to idealize meaning's advent in time. Put differently, it is a view that self-reflectively takes account of our existential predicament and of the need to take full responsibility for the meanings we creatively project. This approach offers a more temperate attitude toward law than the one Cover espouses-particularly in his final essays, in which messianic immediatism, lawful messianism, and the eschatology of law are expressly embraced.

The post-modernized liberal viewpoint that I am defending here may be summed up as follows: Law is as paradoxical as humanity. It is a creative relation, tensely drawn between faith in meaning's advent and suspicion of its coercive conceits. Critical reflection upon the hard reality of human violence and finite understanding gives birth to prudence and moderation, the progeny of our uncertainty. Inherited legal texts and processes, interpreted against the backdrop of history, particularly our constitutional history, with full cognizance of the reality principle of violent jurispathology, serve to con-

208. Cover also loses sight of the principle that political authority cannot be vindicated on the basis of a privileged insight, denied the rest of us, into a moral universe. As Ackerman puts it: "A power structure is illegitimate if it can be justified only through a conversation in which some person (or group) must assert that he is (or they are) the privileged moral authority . . . ." B. ACKERMAN, supra note 6, at 10-11.

209. Consider the externalization of accountability captured in Hannah Arendt's description of Himmler: "[I]nstead of saying: What horrible things I did to people! . . . [the trick was] to say: What horrible things $I$ had to watch in the pursuance of my duties, how heavily the task weighed upon my shoulders!" H. ARENDT, EICHMANN IN JERUSALEM 106 (2d ed. 1977), quoted in E. SCARRY, THE BODY IN PAIN 58 (1985). Consider also the psychology of externalization in the context of delusional beliefs. See Maher, Anomalous Experience and Delusional Thinking: The Logic of Explanations, in Delusional Beliefs 15, 20-25 (T. Oltmanns \& B. Maher ed. 1988) (asserting that delusional beliefs are formed in order to explain anomalous experiences).

210. See A. CAMUS, supra note 1, at 294-306 (rebellion must be grounded in moderation: "Either this value of limitation will be realized, or contemporary excesses will only find their principle and peace in universal destruction."). 
strain the creative surplusage of a moment's vision in fragmenting time. This vital inheritance contextualizes our normative interpretations and the commitments that they engender by situating them within a specific normative reality. ${ }^{211}$ That reality is for us a constitutional reality; it is a reality that grows out of the liberal tradition. To say we have outgrown that tradition is to conclude that we have also outgrown one of its most noble achievements: the establishment of a supreme constitutional law and a tradition of incessant, but tolerant discourse and debate. It is by virtue of this tradition that our collective efforts to translate (and retranslate) constitutional ideals into social and legal practices remain alive and well.

Camus once said that only moderation saves us from the madness of excess. $^{212}$ Similarly, within the law's field of pain and death, only prudence and critical reflection will save us from prideful denial of the imperfections of finite understanding. ${ }^{213}$ In today's world it may well be a highly unusual capacity that enables us appropriately to constrain the creative advent of meaning and the compelling force of illiberal belief. But unusual or not, the legal interpretive project of finite understanding requires no less if we are to act and judge wisely in a free and pluralistic union.

\section{VI. ' CONCLUSION}

Violence is the supreme gesture of closure toward the other. It constitutes a world of unreason where discourse is no longer possible. ${ }^{214}$ That which enhances discourse enriches civil society. That which destroys discourse threatens civil society. A society that stands helpless in the face of that which threatens its existence cannot long endure. ${ }^{215}$ Thus, liberals accept the reality of the law's violence. They do so, however, in order that untrammeled discourse in particular, and civil interests generally, may safely flourish. The

211. Cf. E. LEviNAS, supra note 15, at 17-21 (the system of laws we must impose on ourselves to remain free must deal with the individual as an individual; laws imbedded in sheer abstraction or violence share the common fault of avoiding individuality, thus guaranteeing tyranny); Cornell, supra note 14, at 1192 ("[L]aw is not morality in the sense of the specific commitments of the individual conscience. It is the containment, if not the confinement, of legal judgment on a horizon of ethical understanding, which allows for the perpetuation of a potentially coherent narration of legal principles, irreducible to the mere opinion of the individual judge."); Rawls, supra note 28, at 247 (noting that as a liberal political conception, justice as fairness relies for its reasonableness upon generating its own support "by addressing each citizen's reason, as explained within its own framework").

212. A. Camus, supra note 1 , at 301 .

213. See generally A. Camus, The Fall (1957).

214. Cf. R. Cover, supra note 84, at 5 (referring to Herman Melville's Billy Budd, a tale in which the stammering title character struck in the face of injustice because he could not speak).

215. Cf. J. LOCKE, supra note 6, at 172 (noting that if anyone were to "presume to violate the laws of public justice and equity, established for the preservation of [civil interests], his presumption is to be checked by the fear of punishment, consisting of the deprivation or diminution of those civil interests, or goods, which otherwise he might and ought to enjoy"). 
legitimation of violence within the framework of liberalism is dependent upon broad consensus regarding foundational ideals. I have argued that untrammeled discourse is a foundational ideal that warrants our interpretive commitment. Its unique virtue lies in its ability simultaneously to safeguard and constrain that which accounts for our humanity above all else: intersubjective communication. To speak and be heard is the human reality par excellence. Contingent upon the strength of this historically situated, liberal constitutional understanding, meaning and power shall maintain their originary union in the law.

On this analysis, violent resistance to legally constituted authority may be warranted, but only under carefully limited conditions. Contrary to Cover's claim, those conditions require more than the willingness to back a belief in blood. They are circumscribed by a supreme constitutional law, and the violence they warrant takes place within the normative reality which that supreme law constitutes. Equating law with any belief sufficient to inspire violence on its behalf increases prodigiously the instability of our social world and the violent potential of the law. Cover himself vividly demonstrated the danger of such an understanding of law when he turned toward lawful messianism and when he explicitly endorsed violence as an acceptable means of lawmaking. The danger is precisely this: when law unites with illiberal belief, the fate of the disbelieving other is sealed; she can be neither properly addressed nor properly understood. In this way, lawful messianism opens the way either to violent disunion or to an oppressive social world where civil discourse becomes a mockery.

Still, in several significant respects Cover was right. For example, we may agree that it is the force of our interpretive commitments, our willingness to back a belief in blood, if need be, that holds our normative world together. In a time of uncertain belief, however, the temptation to break free of traditional liberal constraints upon belief for the sake of a more determinate and consoling orthodoxy is strong. For this and other reasons, Cover's pre-messianic embrace of multiple normative worlds is unlikely to inspire much commitment. For one thing, its very openness deprives it of coherence. Moreover, the polynomial vision that ecstatically dissolves our national traditions simultaneously robs us of any meaningful sense of shared historical or cultural identity. In addition, the anarchic bliss that underlies this vision (to the extent it is experienced at all) is extremely difficult to maintain. Thus, it should hardly surprise us to witness the anarchist's eventual leap into fundamentalism.

The leap to illiberal belief is another reason to reject Cover's pre-messianic polynomialism. Its lack of constraint is an invitation to dangerous extremes. Opening the law's violence to the totalizing force of illiberal belief enhances the risk that discrete dialects, and the rhetorical communities that those dia- 
lects constitute, may be cast out from the institutions of power whose doors open to the words of an official discourse only. Once allowed to achieve privileged status in society, a dominant language of power tends to mute alternative forms of discourse. Thus, the ascendancy of legalized prophecy places at risk not only the legitimacy of the exiled other's legal claims, but also the legitimacy of the normative universe that she inhabits.

In light of the foregoing critique, perhaps Cover's most valuable contribution may be put as follows: Only after reencountering (or, if we are fortunate, by anticipating) the chaotic violence spawned by radically opposing beliefs do we come to appreciate (perhaps even strongly enough to practice) the wisdom of liberal constraint. Repulsing the chaos of polynomial fecundity on the one side and totalitarian belief on the other, liberalism finds the bounds within which untrammeled discourse may safely flourish.

But in a time of insecure belief, can the wisdom of the liberal vision inspire commitment without the help of harsher lessons in human folly? Do we need to encounter the reality of violence before the liberal repulsion from illiberal belief regains its strength? Is potential violence enough to teach selfconstraint? Is the possibility of dialogic dominance and the disempowerment that it entails enough to renew our appreciation of the discourse ideal for which discursive constraints are established in the first place-that is, as a necessary check against tyranny?

It would be a fitting irony for the illiberal believer to school us in the virtues of liberal constraint. Thus would the post-messianic Cover teach, if we let him, the dangers of taking too closely to heart his pre-messianic invitation to foster new normative worlds. For upon closer critical examination, we find that it is within the framework of a particular normative reality-the discursively constrained historical reality of liberalism - that Cover's invitation to normative pluralism can be most meaningfully (which is to say, coherently and reliably) extended. Whether this lesson may be learned without unduly adding to the fields of pain and death that have already claimed so many is the true test of our liberal beliefs today. 


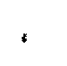

